\title{
Die bepaling van ons mees geliefde Afrikaanse kerklied - 'n metodiese ondersoek \\ Determining our most beloved Afrikaans church hymn - a methodical research strategy
}

\author{
Gideon ElS
}

Skool vir Rekeningkunde

Universiteit van Johannesburg

Suid-Afrika

E-pos: gideone@uj.ac.za

(iD) 0000-0003-0763-7605



Gideon Els

GIDEON Els studeer aan die Randse Afrikaanse Universiteit (RAU) en die Universiteit van Johannesburg (UJ) en behaal doktorsgrade in Ekonomie (1998) en Ouditkunde (2007). Ná 11 jaar as onderwyser word hy in 2000 as senior lektor in Rekeningkunde aan die RAU aangestel. Sedert 2005 is hy medeprofessor in Rekeningkunde aan UJ. Hy het al bykans 50 magisterstudente en 11 doktorale studente suksesvol begelei in die verwerwing van hul onderskeie nagraadse kwalifikasies. Sy navorsing fokus op Besigheidsgeskiedenis, Finansiële Verslagdoening en Navorsingsmetodologie. Hy is die outeur en redakteur van vele sekondêre en tersiêre handboeke in die velde van Finansiële Rekeningkunde, Koste- en Bestuursrekeningkunde asook Finansiële Bestuur. Hy is verder ook die redakteur van 'n geakkrediteerde akademiese vaktydskrif en publiseer gereeld.

Gideon is reeds meer as 33 jaar lank kerkorrelis en begeleier. Hy is ook 'n ywerige komponis, verwerker en orkestreerder. Van sy komposisies vir koor en orkes is al deur die Kaapstadse Filharmoniese Orkes en die Johannesburgse Feesorkes saam met die Simfoniekoor van Johannesburg uitgevoer.
Gideon Els studied at the Rand Afrikaans University (RAU) and the University of Johannesburg (UJ) and obtained doctorates in Economics (1998) and Auditing (2007). Following a teaching career of 11 years, he was appointed as senior lecturer in Accounting at the RAU in 2000. Since 2005 he has been associate professor in Accounting at UJ. He has supervised almost 50 master's students and 11 doctoral students in the successful achievement of their respective postgraduate qualifications. His research focuses on Business History, Financial Reporting and Research Methodology. He is the author and editor of many secondary and tertiary textbooks in the fields of Financial Accounting, Cost and Management Accounting as well as Financial Management. $\mathrm{He}$ is the editor of an accredited academic journal and has published widely.

Gideon has been a church organist and accompanist for more than 33 years. He is furthermore an avid composer, arranger and orchestrator. Some of his compositions for choir and orchestra have been performed by the Cape Town Philharmonic Orchestra and the Johannesburg Festival Orchestra together with the Johannesburg Symphony Choir. 


\section{ABSTRACT}

Determining our most beloved Afrikaans church hymn - a methodical research strategy For more than 60 years, the BBC has been broadcasting Songs of Praise weekly - a religious television programme featuring Christian hymns and songs sung in churches and places of worship from various denominations across the United Kingdom (UK). In 2013, Songs of Praise conducted a national survey to determine the country's favourite hymn. From thousands of entries the hymn How great Thou art emerged as the winner. In 2019, the research was repeated, and viewers indicated that their favourite hymn this time is CH Hubert Parry's Jerusalem.

So, what is the most beloved hymn or song in the various Afrikaans-speaking congregations in Southern Africa? With the kind support of the Southern African Church and Concert Organists Society (SAKOV), the researcher decided to embark on this project to find the most beloved church hymn in Afrikaans-speaking churches in Southern Africa.

This article provides an explanation of the process and results of using a self-administered online survey and questionnaire in determining this most beloved hymn/song. Attention is paid to aspects such as the choice of method, sampling of respondents, questionnaire design and the statistical analysis of responses. Some of the risk-reduction strategies used by the researcher are also highlighted.

The most obvious problem with such a research project is where one will start with the selection of these "favourite" hymns? To determine a workable population of hymns, it was decided to focus only on the population of hymns and songs currently in use in the various Afrikaans-speaking churches in Southern Africa taken from four different sources. From May 2020, the researcher, using the Delphi technique, and a panel of experts compiled a consensus sample of these hymns (Phases 1 and 2 of the research project), which was then used as a population from which the most beloved church hymn/song could be determined (Phase 3 of the research project).

In the third phase of the research project, respondents were expected to complete a survey in the form of an online questionnaire that consisted of open-ended and close-ended questions. There was also a section where they could exercise their ranking choices regarding their favourite hymn/song where an ordinal measurement scale was used. As participation in the research project was voluntary and the probability of a member of the target population responding unknown, non-probability sampling was used in the research.

Females, with a mean age of 57,75 years, were the majority of the sample respondents. About 133 respondents came from the Gauteng province of whom most (83 each) are members of and organists in their respective congregations. Other important roles that respondents played in their respective congregations were that of music leader/director as well as the organist/pianist of the congregation (25) and also the pastor of the congregation (24). The majority of respondents (147) came from the Dutch Reformed Church.

In determining the most beloved hymn, respondents had to place their favourite hymns/ songs in a ranking of choice. The final choice of hymns/songs was therefore based on the product of weighted rankings.

From the analysis congregants showed a clear preference for hymns from the Liedboek (Afrikaans Hymnal) and Psalmboek (Afrikaans Psalms) but that they were also partial to the singing of church songs from both VONKK and FLAM (these two "hymnals" contain more modern and contemporary Afrikaans songs and hymns for church use). It is furthermore noticeable that the Psalms in the official Afrikaans hymnal still play an important role in the spirituality of many of the Afrikaans-speaking churches in Southern Africa. 
This article contributes to the methodological debate in the research field of Church Music.

KEYWORDS: $\quad$ choice of method; church hymn/song; self-administered online questionnaires; Delphi technique; weighted rankings; Afrikaans hymnal

TREFWOORDE: opnametegniek; kerklied; self-geadministreerde vraelyste; Delphitegniek; geweegde gemiddelde; Liedboek

\section{OPSOMMING}

In hierdie artikel word 'n uiteensetting gegee van die proses en die resultate van die gebruik van 'n self-geadministreerde aanlyn opname en vraelys om die mees "geliefde" kerklied in Afrikaanssprekende gemeentes in Suid-Afrika te bepaal. Daar word aandag gegee aan aspekte soos die keuse van metode, steekproefneming van respondente, vraelysontwerp en die statistiese ontleding van response. Sommige van die risikoverminderingstrategieë wat die navorser gebruik, word ook uitgelig. Uit die ontleding van die data is dit duidelik dat gemeentes 'n voorkeur toon vir kerkliedere uit die Liedboek en Psalmboek, maar dat daar duidelik ook 'n liefde is vir liedere uit beide die VONKK- en FLAM-genre. Dit is verder ook duidelik dat die Psalms (al is dit net 'n paar) in die amptelike Afrikaanse Liedboek steeds 'n belangrike rol speel in die spiritualiteit van baie van die Afrikaanssprekende gemeentes in Suider-Afrika. Hierdie artikel dra by tot die metodologiese debat in die navorsingsveld van kerkmusiek.

\section{Inleiding}

Sedert Oktober 1961 saai die BBC weekliks Songs of Praise uit. Dit is 'n godsdienstige televisieprogram wat Christelike liedere aanbied wat in kerke en plekke van aanbidding uit verskillende denominasies van oor die hele Verenigde Koninkryk (VK) gesing word (Barr, 2006). In 2021 vier die program sy 60ste bestaansjaar en daar skakel nog steeds meer as 2,5 miljoen mense weekliks in.

In 2013 het Songs of Praise 'n nasionale opname ${ }^{1}$ gedoen om die land se gunstelingkerklied te vind. Na aanleiding van duisende inskrywings het die Engelse bevolking gestem vir How great Thou art - 'n lied met 'n oorspronklike Sweedse melodie en Engelse woorde vertaal deur Stuart K Hine (BBC, 2013). In 2019 is die navorsing herhaal en het kykers aangedui dat hul gunstelinglied Jerusalem is. Die lied, met woorde deur William Blake en 'n melodie uit 1916 deur Sir CH Hubert Parry, het vir die eerste keer op die Top-10-lys van gunstelingliedere beland (British Period Dramas, 2019).

Wat is dus die mees geliefde kerklied in die onderskeie Afrikaanssprekende gemeentes in Suider-Afrika? Met die goedgunstige ondersteuning van die Suider-Afrikaanse Kerk- en Konsertorrelistevereniging (SAKOV), het die navorser besluit om hierdie projek aan te pak om sodoende te probeer vasstel wat Afrikaanssprekende kerke in Suider-Afrika se gunstelingkerklied is.

In die navorsingsproses kon die outeur glad nie enige inligting bekom oor die metodiek óf fokus van die opname wat deur die BBC gebruik is nie. Verskeie e-posse aan die produksiespan het onbeantwoord gebly. 
Die ooglopende probleem met so 'n navorsingsvraag is waar om te begin met die keuse van hierdie "gunstelingkerkliedere"? Ten einde 'n werkbare populasie van kerkliedere te bepaal, is daar eerstens besluit om net te fokus op die liedereskat wat in die onderskeie Afrikaanssprekende kerke in Suider-Afrika gebruik word. Vanaf Mei 2020 het die navorser, deur gebruikmaking van die Delphi-tegniek en 'n paneel van kundiges, 'n konsensussteekproef van hierdie kerkliedere saamgestel, wat toe gebruik is as 'n populasie waaruit die mees geliefde kerklied bepaal kon word (Els, 2020).

Die doel van hierdie artikel is dus om op 'n narratiewe wyse die proses en uitslae met die bepaling van die gunstelingkerklied in Afrikaanssprekende gemeentes in Suider-Afrika te beskryf.

\section{Keuse van liedere}

Indien al die "amptelike" kerkliedere (m.a.w. liedere uit die Liedboek van die Kerk (2001); Psalmboek (2003); die Projekspan vir Nuwe Musiek, beter bekend as FLAM (2020); en die Voortgesette Ontwikkeling van Nuwe Klassieke Kerkmusiek, beter bekend as VONKK (2020)) wat moontlik in Afrikaanssprekende gemeentes gesing kan word, bymekaargetel word, is daar oor die 1600 liedere om van te kies en dit is onmoontlik om 'n ingeligte keuse uit so 'n groot populasie te maak. Alhoewel die Nuwe Apostoliese Kerk in Suid-Afrika wel 'n Afrikaanse Gesangboek in 2017 vrygestel het (NAC Today, 2017), het die navorser nie hierdie liedere in die populasie van kerkliedere ingesluit nie, aangesien die navorsing merendeels op die sogenaamde Afrikaanse "Susterskerke" gefokus het.

Om deur middel van die navorsing te bepaal watter kerkliedere lidmate in Afrikaanssprekende gemeentes se gunstelinge is, het die navorser gebruik gemaak van die bekendste bronne van kerkliedere. Dit het ingesluit:

- Liedboek van die Kerk (2001) wat uit 150 Psalms en 452 Gesange/Liedboekliedere bestaan

- Psalmboek (2003) wat uit 150 Psalms en 72 Skrifberymings bestaan

- $\quad V O N K K$-liedere (2020) wat uit 422 VONKK-liedere, aanlyn beskikbaar, soos op 31 Mei 2020 bestaan

- FLAM-liedere (2020) wat uit 565 FLAM-liedere, aanlyn beskikbaar, soos op $31 \mathrm{Mei}$ 2020 bestaan

Dit is nie die doelwit van hierdie artikel om die wesenswaarde van die kerklied per se te bespreek nie. Wat meer van toepassing is, is hoe lidmate in Afrikaanssprekende gemeentes die kerklied ervaar en aanvaar en daarmee saam 'n uitspraak kan lewer oor watter van die groot aantal liedere hul gunsteling is. Verder moet dit ook duidelik gestel word dat hierdie navorsing nie ten doel gehad het om die onderskeie bronne van die kerklied of verskillende denominasies teenoor mekaar af te speel nie.

Nie net het die kwantum van liedere wat beskikbaar was vir moontlike keuse 'n tekortkoming in die navorsing teweeg gebring nie, maar was die keuse tussen tradisionele en kontemporêre liedere ook problematies, soos tereg deur die literatuur uitgewys is.

Oor die jare het die Afrikaanse kerklied 'n "vernuwing" ondergaan met Papenfus (1994) wat sinspeel op die vernuwing as die gebruik van die "informele" tesame met die "tradisionele". Kloppers (2003) dui aan dat die proses van vernuwing van die kerklied alreeds begin plaasvind het met die publisering van die Liedboek van die Kerk in 2001 deurdat dit verskeie liedvorms en -style geakkommodeer het. 
Nádat lidmate aangedui het dat die Liedboek van die Kerk (2001) nie genoeg kontemporêre musiek bevat nie, het die Algemene Sinode van die NG Kerk in 2002 'n projekspan daargestel wat getaak is om nuwe Afrikaanse kontemporêre kerkmusiek op 'n deurlopende basis te skep en bevorder. Die Projekspan het later as FLAM bekend gestaan (FLAM, 2020).

Volgens die Algemene Sinode van die NG Kerk in 2007 is VONKK, of te wel die Voortgesette Ontwikkeling van Nuwe Klassieke Kerkmusiek, se doel om “... voortdurend nuwe en ook inheemse [klassieke] kerkmusiek [te] skep en versamel ..." in aansluiting by die kerkliedere soos vervat in die Liedboek van die Kerk (VONKK, 2020). Sedert 2016 is die Nederduitsch Hervormde Kerk ook 'n volwaardige vennoot van VONKK (VONKK, 2020).

Kruger (2007) verwys na die groei in die aantal kerkliedere wat nou beskikbaar is asook die verskillende musiekstyle wat hierdie kerkliedere verwoord. Sy dui ook egter aan dat net sowat 9\% van alle kerkliedere wat sedert die Reformasie ontstaan het, die toets van die tyd deurstaan het (Kruger, 2007:652).

Volgens Kruger (2007) verwag die moderne kerkganger dat die kerklied 'n [konstante] vernuwing moet ondergaan. Dit bring egter mee dat die "persoonlike smaak en kultuur van die lidmaat ..." nou ook in ag geneem moet word (Kruger, 2007:651). Sy voeg dan by dat dit onomwonde beteken dat lidmate gaan verskil oor wat vir hulle aanvaarbaar is, al dan nie.

Hierdie verskil in die aanvaarding van "nuwe" liedere het gedraai rondom aspekte van (i) die uitermate kontemporêre styl van kerkmusiek (Heyns, 1988; Temmingh, 1993; Troskie, 1992; Van der Merwe, 1993); (ii) die argument oor die sekulêre teenoor die geestelike of sakrale (Kruger, 2007); en (iii) die invloed van die charismatiese musiekstyl op hedendaagse kerkliedere (Viljoen, 2006).

Dit is juis hierdie vorm van "tradisionele" of "kontemporêre" kommunikasie wat vir baie lidmate soms 'n probleem is. Deborah Justice (2010) verwoord dit so mooi waar sy opmerk: "Organs versus guitars, hymns versus praise choruses, a choir versus a band ... [i]n deciding upon which of such 'worship elements' define 'us' versus 'them', religious groups discern a combination of sonic, social, and sacred factors ...".

\section{Navorsingsmetodiek in die volledige navorsingsprojek}

Ten einde die risiko van subjektiwiteit in 'n navorsingsprojek soos hierdie te minimaliseer, het die navorser besef dat daar van statisties beproefde navorsingsmetodes gebruik gemaak moet word om geldigheid en betroubaarheid te behou. Die volledige navorsingsprojek is toe in drie fases verdeel.

- In Fase 1 van die navorsingsproses het die navorser 'n loodsstudie gedoen deur van 'n klein gekose groep respondente gebruik te maak ten einde die inhoudsgeldigheid van die navorsing te toets.

- In Fase 2 van die navorsingsproses het die navorser van 'n Delphi-studie asook van 'n paneel van kundiges gebruik gemaak. Die Delphi-tegniek is 'n algemeen aanvaarde navorsingsmetodiek wat gebruik word vir die voorspelling van uitkomste gebaseer op die resultate van vraelyste wat in verskeie rondtes aan 'n paneel van kundiges gestuur is (Hirschhorn, 2019; Sekayi \& Kennedy, 2017). Die paneel van kundiges het drie vraelyste oor 'n maksimum periode van twee maande ontvang wat hulle moes voltooi ten einde die finale konsensussteekproef van kerkliedere te bepaal wat die navorser dan in die derde fase van die navorsingsprojek gebruik het. 
Die volledige bespreking van die navorsingsmetode en uitkomste wat gepaard gegaan het met die eerste twee fases van die navorsing is alreeds gepubliseer, maar word kortliks in afdeling 4 bespreek (Els, 2020).

- In Fase 3 van die navorsingsproses is die konsensussteekproef van kerkliedere aan 'n steekproef van respondente voorgelê. Hulle moes dan hul gunstelingliedere in die vraelys in rangorde plaas. Deur middel van data-ontleding is daar toe bepaal wat die deursneelidmaat in Afrikaanssprekende gemeentes se gunstelingkerklied is.

\section{4. 'n Beknopte oorsig van die eerste twee fases van die navorsingsprojek}

FIGUUR 1 dui skematies 'n samevatting aan van hoe die navorser te werk gegaan het om die eerste twee fases van die navorsingsprojek te administreer (Els, 2020). Dit verskaf ook 'n opsomming van die responskoers wat in die onderskeie rondtes verkry is. Hierdie aspekte sal hier onder kortliks bespreek word.

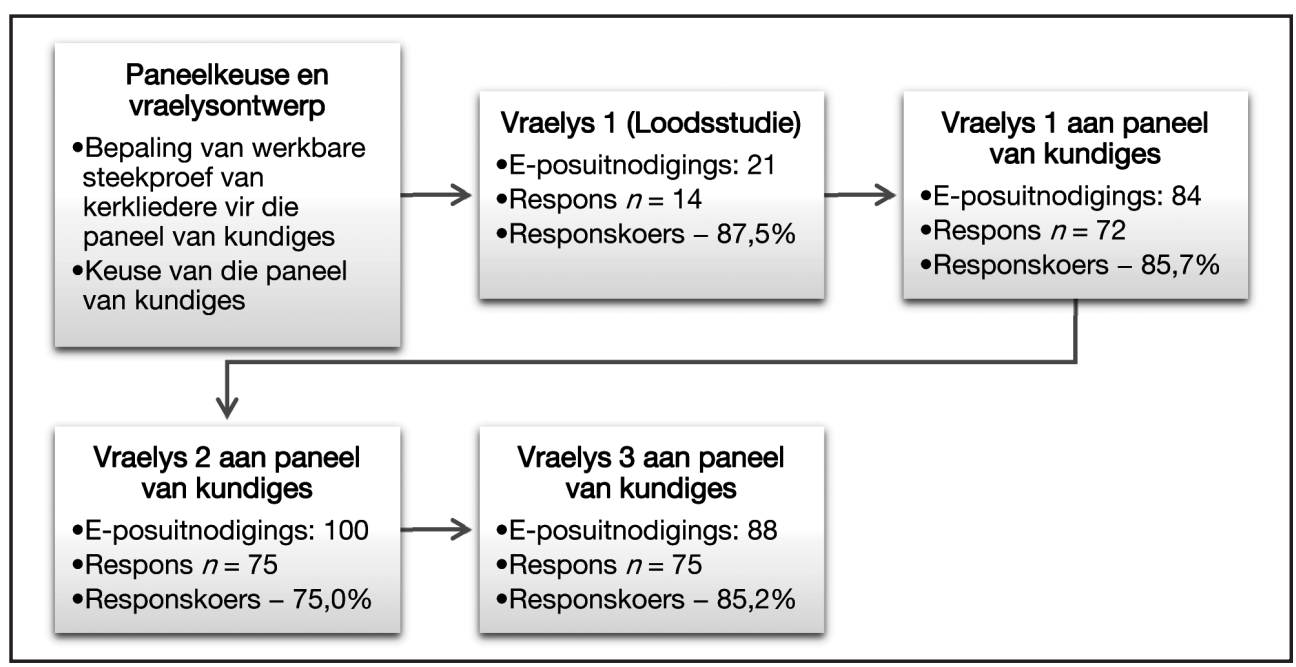

Figuur 1: $\quad$ Vloeidiagram ter illustrasie van die onderskeie opnamerondtes in die eerste twee fases van die Delphi-studie

Bron: Navorser se samevatting

* By Vraelyste 2 en 3 sluit $n$ die loodsstudie-respondente in

\subsection{Fase 1: Loodsstudie}

\section{Vraelys-ontwerp}

Soos vroeër genoem, het die navorser in die beplanning van die vraelys van vier bronne gebruik gemaak, wat as die populasie vir die onderskeie kerkliedere in Afrikaanssprekende gemeentes sou dien. Dit het ingesluit 150 Psalms, 452 Gesange/Liedboekliedere en 79 Skrifberymings uit die Liedboek van die Kerk (2001) en die Psalmboek (2003), sowel as alle beskikbare VONKK-liedere (422) en FLAM-liedere (565) soos aan die einde van Mei 2020 aanlyn gepubliseer is. Tot en met einde Mei 2020 was daar dus 1662 "amptelike" kerkliedere wat 
moontlik in Afrikaanssprekende gemeentes gesing kon word (volgens die bronne wat vroeër in Afdeling 2 beskryf is).

Die navorser het op grond van meer as 30 jaar ondervinding as kerkorrelis deur al hierdie potensiële kerkliedere gewerk en die werkbare steekproef van liedere verminder tot 653 of 39,2\% van die populasie. Dit het bestaan uit 57 Psalms, 249 Gesange/Liedboekliedere, 130 VONKK-liedere en 217 FLAM-liedere. Hierdie steekproef van kerkliedere het nie die Skrifberymings ingesluit nie, aangesien die navorser nie bekend was met die gebruik van die liedere in die Gereformeerde Kerk nie. Paneellede wat verbonde is aan die Gereformeerde Kerk is dus versoek om spesifiek van hulle gunsteling-Skrifberymings in die eerste vraelys te noem.

Die eerste vraelys het dus bestaan uit 'n afdeling wat die demografiese inligting van die respondente versoek het asook die nuwe "populasie" van kerkliedere waaruit hulle kon kies. Die verdere twee vraelyste het nie weer van respondente verwag om demografiese inligting te verskaf nie. In die eerste twee vraelyste is daar ook oopresponsvrae aan respondente gegee waarin hulle enige liedere wat nie in die vorige vraelys opgeneem is nie, kon deurgee.

\section{Keuse van loodsstudiepaneel}

Voordat die eerste vraelys aan die paneel van kundiges gestuur is, het die navorser sekere lede van die paneel van kundiges gekies om as 'n loodsstudie deur die vraelys te werk. Ooglopende foute en/of tekortkominge is deur hierdie respondente uitgewys en deur die navorser verbeter vir insluiting in die finale vraelys.

Verder het die loodsstudie uitgewys dat daar nog steeds liedere in die steekproef verskyn het wat glad nie aanklank by respondente gevind het nie. Nadat die bestaande liedere verminder is, het die steekproef van liedere nou bestaan uit 51 Psalms, 39 Skrifberymings, 221 Gesange/ Liedboekliedere, 129 VONKK-liedere en 216 FLAM-liedere vir 'n totaal van 617 kerkliedere of $36,9 \%$ van die populasie.

\subsection{Fase 2: Die Delphi-tegniek en paneel van kundiges}

\section{Samestelling van die paneel van kundiges}

Die samestelling van die paneel van kundiges was 'n belangrike stap in hierdie navorsingsproses om sodoende te verseker dat 'n wye hoeveelheid kennis onderling verteenwoordig word deur die onderskeie paneellede (Hirschhorn, 2019).

Om seker te maak dat die algehele navorsingsprojek sy geldigheid en betroubaarheid behou, het die navorser die amptelike ledelys van SAKOV in die samestelling van die paneel van kundiges gebruik. Deur middel van sneeubalsteekproefneming het die navorser addisionele inligting van potensiële kundiges bekom wat nie noodwendig SAKOV-lede was nie en is die teikenpopulasie tot 592 moontlike paneellede vergroot.

Vervolgens het die navorser van 'n gestratifiseerde steekproef gebruik gemaak om die ewekansigheid van potensiële paneellede te verseker. Dit het onder andere beteken dat die paneel van kundiges moes bestaan uit ' $n$ beduidende steekproef van leraars, orreliste, pianiste, musiekkoördineerders, musiekleiers, lede van instrumentale begeleidingsgroepe (bands) en kerkmusiekkenners gekies vanuit die onderskeie SAKOV-streke (dit sluit al die provinsies in Suid-Afrika in asook SAKOV-lede in Namibië). 


\section{Navorsingsmetode}

In die eerste twee rondtes van die navorsingsprojek is daar van die Delphi-tegniek in die studie gebruik gemaak. Die Delphi-tegniek is 'n iteratiewe proses ten einde anonieme oordele van kundiges te versamel en distilleer deur die gebruikmaking van 'n reeks data-insameling- en ontledingstegnieke wat afgewissel word met terugvoer (Skulmoski, Hartman \& Krahn, 2007). Skulmoski et al. (2017) asook Rowe en Wright (1999) het ook aangedui dat die Delphi-tegniek goed werk om veral voorspellings te ontwikkel - net soos in die geval van hierdie navorsingsprojek waar die navorser 'n konsensussteekproef probeer daarstel het in die bepaling van die mees geliefde kerklied in Afrikaanssprekende gemeentes.

Die Delphi-tegniek is 'n liniêre navorsingsproses wat staatmaak op 'n reeks vraelyste wat onder 'n geselekteerde paneel van kundiges versprei word en wat deur 'n navorsingskoördineerder (in dié geval, die outeur) bestuur word. Nadat 'n vraelys in die eerste rondte voltooi is, gee die navorsingskoördineerder respondente anonieme terugvoer oor response wat deur die paneellede verskaf is. Paneellede kan oor hierdie terugvoer besin en hul menings heroorweeg en dienooreenkomstig daarop in die daaropvolgende vraelyste reageer. Hierdie proses van afwisselende vraelyste en gekontroleerde meningsterugvoer, gaan voort totdat 'n gewenste vlak van konsensus deur die respondente bereik word, of totdat die menings oor die onderskeie opnamerondtes stabiel is (gewoonlik drie) (Hirschhorn, 2019; Sekayi \& Kennedy, 2017).

Hierdie konsensussteekproef van kerkliedere (kyk hier onder) is toe gebruik in die derde fase van die navorsingsprojek, waarin respondente uitgenooi is om deur middel van 'n elektroniese vraelys, vanuit die steekproef, hul gunsteling- Afrikaanse kerkliedere in rangorde van keuse te plaas.

\section{Finale konsensussteekproef van kerkliedere}

In TABEL 1 en FIGUUR 2 word die konsensusbesluite oor die keuse van kerkliedere vir insluiting in die finale steekproef, wat gebruik is as deel van Fase 3 van die navorsing, uitgelig.

TABEL 1: Steekproefkonsensusbesluit van paneel van kundiges

\begin{tabular}{|c|c|c|c|c|c|}
\hline \multirow[b]{2}{*}{ BRON } & \multirow[b]{2}{*}{$\begin{array}{c}\text { Populasie } \\
\text { van liedere }\end{array}$} & \multicolumn{2}{|c|}{ VRAELYS 1} & VRAELYS 2 & VRAELYS 3 \\
\hline & & $\begin{array}{c}\text { Aantal } \\
\text { verkose } \\
\text { liedere** }\end{array}$ & $\begin{array}{c}\text { Aantal } \\
\text { verkose } \\
\text { liedere } * * *\end{array}$ & Aantal verk & sse liedere $* * *$ \\
\hline Psalms & 150 & 51 & 32 & 12 & 10 \\
\hline Gesange/Liedboekliedere* & 452 & 221 & 119 & 63 & 24 \\
\hline VONKK-liedere & 422 & 129 & 50 & 28 & 22 \\
\hline FLAM-liedere & 565 & 216 & 47 & 17 & 19 \\
\hline TOTAAL & 1589 & 617 & 248 & 120 & 75 \\
\hline $\begin{array}{l}\text { Totaal as \% van die oor- } \\
\text { spronklike populasie }\end{array}$ & $100,00 \%$ & $38,83 \%$ & $15,61 \%$ & $7,55 \%$ & $4,72 \%$ \\
\hline
\end{tabular}

Bron: Samevatting deur outeur

* Waar moontlik is Skrifberymings met dieselfde melodie hierby ingesluit.

** Die steekproef van liedere wat hier ingesluit is, het as deel van die loodsstudie na vore gekom.

*** Die aantal verkose liedere per vraelys is gegrond op ' $n$ konsensusbesluit van die paneel van kundiges. Hierdie liedere is dan in die volgende vraelys in Fase 3 van die navorsingsprojek as deel van die steekproef ingesluit waaruit die paneel kon kies. 


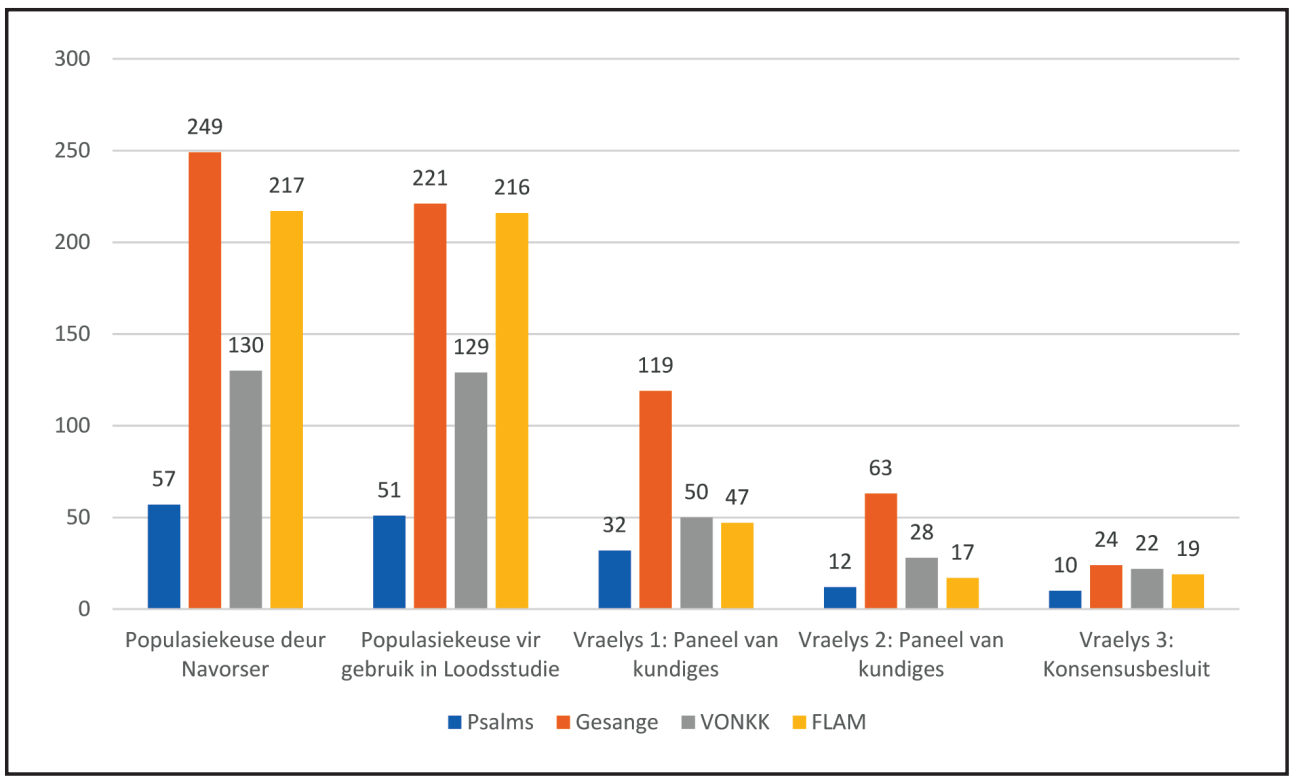

Figuur 2: $\quad$ Konsensusbesluit oor die keuse van kerkliedere Bron: SPSS 26

\section{Fase 3 van die navorsingsprojek}

\subsection{Navorsingsmetodiek}

\section{Opname-navorsing}

Opname-navorsing, saam met die gebruik van toepaslike vraelyste, is die mees gebruikte metode vir die insameling van data in die sosiale wetenskappe (Shermis \& Lombard, 1999; Sproull, 1986). Literatuur dui egter aan dat die gebruik van opname-navorsing nie meer so populêr soos tevore is nie. Blumenberg, Menezes, Gonçalves, Wehrmeister en Barros (2019) wys daarop dat opname-navorsing 'n konstante afname in responskoerse ondervind, wat na raming tussen een en twee persentasiepunte per jaar beloop.

Oor die afgelope jare is daar bevind dat sogenaamde tradisionele opnamemetodes - wat per pos, persoonlik of telefonies geskied - deesdae ondoeltreffend is as gevolg van, onder andere, die kwaliteit van die posstelsel (Blumenberg et al., 2019).

Meer onlangs het die gebruik van elektroniese, self-geadministreerde vraelyste 'n aantreklike alternatief tot fisiese onderhoudvoering geword (Jacobs, 1995; Kraut, 1984; Norman, Friedman, Norman \& Stevenson, 2001). Dit is veral meegebring deur verhoogde toegang tot rekenaarfasiliteite en die gebruik van die internet. Norman et al. (2001) het ook aangetoon dat aanlyn opnames en vraelyste op verskillende maniere geïmplementeer kan word. Omdat aanlyn opnames ook interaktief is, behoort dit hoër responskoerse te kry (Shermis \& Lombard, 1999).

In hierdie fase van die navorsingsprojek is daar van respondente verwag om 'n opname in die vorm van 'n aanlyn vraelys te voltooi. 
Die lengte van vraelyste in opname-navorsing speel 'n groot rol in die responskoers. Literatuur wys dat korter vraelyste 'n groter kans het om voltooi te word (Johnson, Siluk \& Tarraf, 2014). Blumenberg et al. (2019) het aangetoon dat die uitstuur van 'n herinnering per e-pos aan niereageerders die responskoers positief beïnvloed. Die outeurs het ook gevind dat die lengte van 'n vraelys nie soseer 'n statisties merkbare invloed op die responskoers het nie. In die konteks van hierdie studie het die gebruik van 'n langer vraelys dus nie die responskoers in gevaar gestel nie.

Alhoewel die responskoers alleen nie 'n bewys van navorsingskwaliteit en -geldigheid is nie, is dit 'n belangrike komponent in die totale opnamefout. Deur die bereiking van hoë responskoerse word die waarskynlikheid van 'n nie-reaksiefout verminder en op sy beurt word die waarskynlikheid om bevooroordeelde beramings te verkry ook verminder (Blumenberg et al., 2019). Die nadelige gevolge van die niereaksie op die uitkomste van vrae word al vir jare bestudeer. Vraagsensitiwiteit dra ook by tot hoër niereaksiesyfers (Shoemaker, Eichholz \& Skewes, 2002).

Die responskoers van toepassing op hierdie navorsingsprojek sal later in die afdeling volledig bespreek word.

\section{Aspekte van vooroordeel}

In 'n subjektiewe navorsingsprojek soos hierdie, is dit belangrik om sekere waardes rakende die beheer van vooroordeel, die behoud van objektiwiteit tydens die navorsingsproses en gevolgtrekkings uit die studie in gedagte te hou (Collis \& Hussey, 2009).

Verskeie "foute" en vooroordele kan moontlik ontstaan as daar van aanlyn selfgeadministreerde vraelyste gebruik gemaak word. In hierdie studie is daar duidelik pogings aangewend om aandag aan niedekking, steekproefraamsydigheid, item-niereaksie, uitvalkoers, sosiale wenslikheids-vooroordeel en selfseleksiesydigheid te gee.

Niedekking verwys na die gebrek aan internettoegang (Couper, Kapteyn, Schonlau \& Winter, 2007). Fan en Yan (2010) het verduidelik dat dekkingsfoute kan lei tot 'n nieverteenwoordigende steekproef van die teikenpopulasie en as gevolg daarvan kan die bevindings nie veralgemeen word nie. Vraelyste wat per e-pos versprei word, kan ook 'n vooroordeel van steekproefvoorstelling lewer, aangesien sommige respondente moontlik nie internettoegang het nie (Dodge \& Chapman, 2018). Vir die doeleindes van hierdie navorsingsprojek is daar van die amptelike SAKOV-lededatabasis gebruik gemaak waar lede se e-posadresse aangedui word. In gevalle waar nie-SAKOV-lede deur middel van 'n e-pos geteiken is, het die navorser 'n geldige e-posadres vir die respondent gehad. Die gebrek aan internettoegang tot die onderskeie VONKK- en FLAM-liedere kon moontlik tot nadeel van sommige respondente gewees het. In gemeentes waar die liedere wel gesing word, sou die musikant(e) wel toegang tot die liedere gehad het deurdat die gemeente self dan die liedere sou beskikbaar gestel het.

Item-niereaksie is ' $n$ bron van kommer in enige self-geadministreerde aanlyn vraelys, aangesien respondente nie al die items kan/wil invul as hulle deur die vrae werk nie (Denscombe, 2009). Hierdie probleem is hanteer deur in die eersterondte-vraelys van die vrae as verpligtend te kodeer. Al hierdie vrae moes dus beantwoord word voordat respondente toegelaat is om na die volgende gedeelte van die vraelys te gaan. Dit kon lei tot 'n hoë uitvalsyfer, aangesien sommige respondente "gedwing" kan voel om al die vrae te voltooi 
(Dodge \& Chapman. 2018). Tourangeau, Conrad en Couper (2013) het egter aangedui dat verpligte kodering van antwoorde nie die uitvalsyfer aansienlik verhoog nie.

Sosiale wenslikheidsvooroordeel verwys na die vooroordeel in reaksies wat veroorsaak word deur respondente se begeerte om 'n gunstige indruk by die navorser te skep (Zikmund et al., 2013). Sommige respondente kan sosiaal wenslike gedrag of houdings oorrapporteer. Verskeie navorsers het egter opgemerk dat sosiale wenslikheidsvooroordeel minder gereeld in self-geadministreerde aanlyn vraelyste voorkom as in die gebruik van die ondervragingsopnames (Heerwegh \& Loosveldt, 2008). Krumpal (2013) wys daarop dat sosiale wenslikheidsvooroordele meer waarskynlik is in opnames wat betrekking op "ongewenste gedrag" het.

Selfseleksiesydigheid kan ook voorkom in die gebruik van die aanlyn vraelyste wat in die navorsingsprojek gebruik is (Zikmund et al., 2013). Hierdie vooroordeel kom voor wanneer respondente wat sterk oor 'n onderwerp voel dan meer geneig is om aan 'n studie deel te neem.

\subsection{Metingsinstrument}

\section{Vraelys-ontwerp}

Die vraelys vir hierdie fase van die navorsingsprojek is ontwerp deur gebruik te maak van die sogenaamde geslote vraagformaat (daar was twee vrae aan die einde van die vraelys wat as oop beskou kan word en waar respondente (i) 'n persoonlike gunstelingkerklied kon voorstel wat nie in die steekproef ingesluit is nie en (ii) enige ander opmerkings kon maak of iets onder die aandag van die navorser bring).

In empiriese, sosiale navorsing is die gebruik van "geslote" vraagformate om die houding en menings van respondente te toets, baie gewild. "Geslote" impliseer dat die reaksiekategorieë van die opname-vraag volledig gespesifiseer word (Höhne \& Krebs, 2018).

Soos met die vraelyste in die eerste twee fases van die navorsingsprojek het die vraelys vir Fase 3 ook bestaan uit ' $n$ afdeling waar respondente hul demografiese inligting kon verskaf en 'n afdeling waar hulle hul rangorde-keuses met betrekking tot hul gunstelingkerkliedere kon uitoefen. Die steekproef van kerkliedere waaruit die respondente kon kies, is saamgestel na aanleiding van die eerste twee fases van die navorsingsproses deur gebruikmaking van die Delphi-tegniek.

\section{Die uitoefen van keuses deur respondente}

Ten einde 'n keuse te kon uitoefen moes respondente die besluit oor hul gunstelingkerklied grond op die beginsel van "recall" of "herroeping". In die keuse van die gunstelingkerklied het die navorser nie verwag dat die gemiddelde kerkganger of lidmaat 'n "akademiese" besluit sou neem op grond van die teks, melodie, toonhoogte, rymskema of ritme nie. Peretz, Gaudreau en Bonnel (1998:885) het bewys dat melodieherkenning (die sogenaamde implicit memory phenomenon) 'n beduidende invloed op die keuse van 'n lied het al dan nie. Vir die doel van die navorsing kon respondente nie na die melodie luister om dan 'n ingeligte besluit te neem nie. Met die paneelstudie (as deel van die eerste twee fases van die navorsing) het baie respondente opgemerk dat hulle uitsluitlik hulle keuse moes uitoefen op grond van die titel van die lied voor hulle en moontlik die naam van die melodie. Dit is egter belangrik om daarop te let dat die meerderheid van die respondente wat deel van die paneel van kundiges uitgemaak het, musici in eie reg was en dat die naam van die melodie dus iets vir hulle sou beteken het.

Vir die deursneekerkganger en -lidmaat sou hulle herroeping eerstens gebaseer wees op die titel van die lied wat byvoorbeeld op die flitsbord in 'n kerk sou verskyn. Daar mag dalk 
kerkgangers wees wat uit liedboekbundels sing (in die geval van die Liedboek of Psalmboek) en die melodie sou sien maar merendeels sou die besluit gegrond gewees het op die titel alleenlik.

In die tipiese Engelse kerktradisie sal die titel van 'n lied (bv. Majesty) onmiddellik by die kerkganger ' $n$ herinnering oproep wat sekere inligting by hulle sal ontsluit. In die tipiese Afrikaanse kerke is dit bietjie moeiliker omdat daar vir soveel jare staatgemaak is op 'n numeriese stelsel in 'n spesifieke bundel van kerkliedere. Met die infasering van die meer kontemporêre liedere (bv. VONKK en FLAM) het daardie tradisie nou begin verander. Kerkgangers bring nie soseer meer liedboekbundels kerk toe nie en hulle word meer gekonfronteer met net die naam of titel van die kerklied wat op 'n flitsbord verskyn en nie soseer die nommer nie. Dit is moontlik waarom die Oorwinningslied (FLAM 57) deur so baie respondente uitgewys is as 'n geliefde of populêre lied-die titel was vir hulle onmiddellik herkenbaar.

In die literatuur word daar onderskei tussen twee soorte geheueherwinning: herkenning versus herroeping. Wanneer jy iemand op straat ontmoet, is dit maklik om dadelik te weet of jy die persoon al ooit gesien of ontmoet het, maar dit is baie moeiliker om daardie persoon se naam te onthou. Die eerste proses is herkenning (jy herken daardie persoon en besef dat hy/ sy aan jou bekend is); die tweede proses behels herroeping.

Herkenning verwys na 'n mens se vermoë om 'n gebeurtenis of stuk inligting (soos die naam van 'n kerklied of die eerste paar note van die lied) as "bekend" te herken, terwyl herroeping is om verwante besonderhede (soos byvoorbeeld die teks of melodie van die kerklied) te onthou. Hollingworth (1913) het opgemerk dat mense gemiddeld twee keer meer kan "herken" as "herroep". MacLachlan (2009) het die "herroeping" van 'n lied vergelyk met die druk van 'n knoppie op 'n bandopnemer waardeur toegang tot 'n persoon se musikale geheue verkry word. Korenman en Peynircioglu (2004) het in 'n studie bevind dat respondente die titels van populêre liedere beter kon herroep as die melodieë van die liedere.

\subsection{Steekproefneming}

Aangesien deelname aan die navorsingsprojek vrywillig was en die waarskynlikheid dat 'n lid van die teikenpopulasie gereageer het onbekend was, is daar van niewaarskynlikheidsteekproefneming in die navorsing gebruik gemaak. Literatuur wys daarop dat die gebruik van niewaarskynlikheidsteekproefneming in navorsing (en veral aanlyn navorsing) goeie resultate oplewer en in sommige gevalle selfs beter is as wat daar van waarskynlikheidsteekproefneming gebruik gemaak is (Lamm \& Lamm, 2019).

Soos met die eerste twee fases in die steekproefneming vir die navorsingsprojek is daar van die amptelike SAKOV-lededatabasis gebruik gemaak waar lede se e-posadresse aangedui word. Op grond van die data het die navorser oor die inligting van 459 lede met e-posadresse beskik. In gevalle waar nie-SAKOV-lede deur middel van 'n e-pos geteiken is, het die navorser 'n geldige e-posadres vir 'n potensiële respondent gehad wat toe die teikenpopulasie tot 656 vergroot het. Die populasie het bestaan uit potensiële respondente vanuit al die provinsies in Suid-Afrika asook Namibië. Anders as met die samestelling van die paneel van kundiges het respondente bestaan uit die gewone Afrikaanse "kerkbevolking".

Vanuit die vraelys het daar baie interessante opmerkings oor die navorsingsprojek gekom met vele van die respondente wat hul waardering vir die projek uitgespreek het. 'n Paar van die opmerkings word hier onder genoem: 
“Dankie vir 'n interessante navorsingstuk!” [Respondent_FIN004]

"Dankie vir die voorreg om deel te neem ... laat ons sing!” [Respondent_FIN053]

“Seën met die prysenswaardige navorsingsprojek!” [Respondent_FIN093]

“Dankie vir die navorsing. Dit is baie nodig." [Respondent_FIN101]

"Dit was 'n lekker en interessante oefening. baie dankie. Ek kan nie vir die resultate wag nie!" [Respondent_FIN225]

“Wanneer die inperkingstyd verby is, sal ek graag so 'n konsert wou sien gebeur met baie stemme wat opklink uit dankbaarheid ..." [Respondent_FIN032]

Een van die respondente het sy/haar mening uitgespreek dat die navorsing neig om 'n "goldie hit parade" daar te stel:

"Ek kan die doelwit van die navorsing insien, maar dit neig vir my te veel na 'n "goldie hit parade". Ek kan eerlikwaar nie regtig so keuse maak nie, miskien 'n Kerslied, of 'n Paaslied, 'n Psalm, maar wat dan van die res wat ek ook ken en van hou? In die gemeente waar ek is word geen VONNK- \& FLAM-liedere gesing nie ... daar moet weer oor die beskikbaarstelling van die liedere gedink word." [Respondent_FIN084]

'n Ander respondent het gevoel dat die navorsing neig om kerke teen mekaar af te speel:

"Ek vind dit jammer dat Totius beryminge (op die oog af) nie opgeneem is nie. Verder dink ek dat in die geval van kerkgemeenskappe wat nie gebruikmaak van die Liedboek, Vonk- en Vlam-liedere [sic] hierdie navorsing akkuraat kan wees nie. Dit sou waarskynlik meer sin maak om hierdie navorsing te fokus op een spesifieke groep (groepering wat gelyksoortige liedere gebruik). Om gemeenskappe soos Gereformeerd, VGK, NG teen mekaar op te weeg maak gewoon nie sin nie. 'n Goeie inisiatief, maar ek dink nie die breë basis maak sin nie." [Respondent_FIN102]

Hierdie opmerking het baie gemeen gehad met 'n opmerking wat deur 'n paneellid in die vorige fases van die navorsingsprojek gemaak is:

“Dit klink vir my na te veel moeite vir 'n oefening wat nie 'n groot bydrae gaan maak wat die gebruik van die veelvuldige liedereskat betrefnie. My mening is dat ons in hierdie era eerder die verskillende spiritualiteite van gemeentes erken en waardeer en probeer "uitbou". Dit sou dus (vir my) van groter waarde wees om te probeer vasstel wel watter liedere gemeentes sing, maar ten einde dan blootstelling te gee aan nuwe en onbekende liedere. Ek stem saam dat die besluitnemers (orreliste, musiekdirekteurs en liturge in gemeentes) kan ly aan 'keuseverlamming'wanneer liedere gekies word, maar gee (na my mening) eerder blootstelling aan méér opsies as dat 'n mens suggesties maak van watter liedere ander gemeentes die graagste sing... Met laasgenoemde verskraal jy eerder die ontwikkeling en uitbreiding van ons liedereskat." [Respondent \#69]

Die konsensussteekproef van liedere waaruit respondente kon kies, was ook vir een respondent 'n "probleem" wat ook gewys het op die spesifieke "spiritualiteit" in 'n gemeente:

"Dit is vir my onmoontlik om EEN lied uit te sonder. Dus is die inligting wat ek gegee het nie waardevol nie! Daar is baie faktore wat 'n rol speel in die geliefdheid van 'n lied: assosiasie, atmosfeer, spesifieke geleentheid, musikale belewenis, teks, persoonlike fase 
van mens se lewe, religieuse verkenning, ens. Sterkte met die projek." [Respondent_ FIN262]

\subsection{Etiese klaring}

Omdat die navorsing deur SAKOV ondersteun is, is etiese klaring vir die navorsingsprojek deur die Uitvoerende Komitee van SAKOV (almal gerespekteerde akademici) toegestaan. Die navorsingsprojek is verder ook as "lae risiko" geklassifiseer. Die doel van die navorsingsprojek en die voordele van deelname aan die navorsing was duidelik in 'n persoonlike e-pos uiteengesit wat aan die respondente gestuur is. Die e-pos het ook 'n skakel na die elektroniese vraelys bevat.

Voordat 'n respondent toegang tot die vraelys kon kry, moes hulle eers 'n toestemmingsvorm voltooi. Die toestemmingsvorm het ' $n$ integrale deel van die vraelys uitgemaak en het duidelik aangedui dat deelname aan die studie vrywillig was en dat geen individu op enige manier negatief geraak sou word indien hy/sy nie wou deelneem nie.

\subsection{Data-insameling}

Vir die doeleindes van hierdie navorsingsprojek, het die navorser uitsluitlik gesteun op tegnologie met die insameling en berging van velddata deur van aanlyn data-insameling gebruik te mak, aangesien daar duidelike voordele is in die gebruik van die metode (Granello \& Wheaton, 2004). Die vraelys is voorberei en aangebied op Google Forms, wat ook beteken het dat die insameling van die data elektronies kon geskied.

Sodra respondente geklik het op die skakel in die persoonlike e-pos wat aan hulle gestuur is, het die vraelys op Google Forms oopgemaak. Respondente het instruksies gekry oor die aard van die taak. Daar is ook duidelik op die eerste bladsy van die vraelys aangedui dat hulle vrywillig deelneem aan die navorsingsprojek. Indien hulle dan sou instem om aan die navorsing deel te neem, het hulle 'n etiese toestemmingsvorm gekry wat hulle moes voltooi. Indien die respondent dit nie voltooi het nie, kon hulle nie met die res van die vrae in die navorsing voortgaan nie.

Die eerste deel van die vraelys het vrae oor respondente se demografie gevra, wat onder andere hul geslag, ouderdom, kerkverband, provinsie, hul rol of betrokkenheid in hul plaaslike gemeente en vir hoe lank hulle al daar betrokke is, ingesluit het.

In die tweede deel van die vraelys is van respondente verwag om groepe kerkliedere in rangorde van gewildheid te plaas. Ten einde vooroordeel uit te skakel, is liedere individueel, per groep volgens een van die vier bronne genoem (byvoorbeeld FLAM- en VONKK-liedere is nie in dieselfde groep gesit nie).

Die gebruik van "rangorde" beteken dat daar van 'n ordinale metingskaal gebruik gemaak word. Nominale en ordinale metingskale staan ook bekend as kategoriese of "kwalitatiewe" metingskale (Kampen, 2019). Die kategorieë van ordinale veranderlikes kan nie in 'n verhouding- of intervalskaal gemeet word nie omdat die sosiale afstand nie kwantitatief gemeet kan word nie. Ten einde 'n meer geldige analise te verkry, word hierdie tipe data gerangskik met rangordekeuses wat dikwels as opeenvolgende heelgetalle van 1 tot $n$ kategorieë gekodeer word (Paudel, Poudel, Dunn \& Pandit, 2009).

\subsection{Verspreiding van die vraelys}

Individuele, persoonlike e-posboodskappe is aan elke potensiële respondent gestuur wat duidelik die doel en werkswyse van die navorsing verwoord het. Respondente kon dan net op 
'n skakel in die e-pos klik wat hulle dan na die vraelys in Google Forms geneem het. Anders as met die eerste twee fases van die navorsingsprojek is daar geen opvolg-e-posse aan potensiële respondente gestuur nie.

TABEL 2 verskaf 'n samevatting van die uitkoms met die verspreiding van die vraelys.

TABEL 2: Uitnodigings aan potensiële respondente om aan die navorsingsprojek deel te neem

\begin{tabular}{|c|c|c|}
\hline \multicolumn{2}{|l|}{ Aantal e-posse aan respondente gestuur } & $656^{*}$ \\
\hline \multicolumn{3}{|l|}{$\begin{array}{l}\text { **Berekening van 'n meer akkurate populasie deur die } \\
\text { weglating van die volgende respondente: }\end{array}$} \\
\hline \multicolumn{2}{|l|}{ Respondente met'n verkeerde e-posadres } & (10) \\
\hline \multicolumn{2}{|l|}{ Vraelys net ter inligting aan loodsstudiegroep gestuur } & (11) \\
\hline \multicolumn{2}{|l|}{$\begin{array}{l}\text { Vraelys net ter inligting aan SAKOV-Streekverteen- } \\
\text { woordigers gestuur }\end{array}$} & (12) \\
\hline \multicolumn{2}{|l|}{$\begin{array}{l}\text { Vraelys net ter inligting aan sekere paneellede gestuur } \\
\text { wat nie die finale vraelys sou/wou beantwoord nie }\end{array}$} & (45) \\
\hline \multicolumn{2}{|l|}{ Potensiële populasie } & 578 \\
\hline \multirow{3}{*}{$\begin{array}{l}\text { Respons*** }(n) \text { op uitnodiging om aan die navorsings- } \\
\text { projek deel te neem }\end{array}$} & $\mathbf{J A}$ & $\begin{array}{c}258 \\
(44,64 \%)\end{array}$ \\
\hline & NEE & $\begin{array}{c}14 \\
(2,42 \%)\end{array}$ \\
\hline & $\begin{array}{c}\text { GEEN } \\
\text { RESPONS }\end{array}$ & $\begin{array}{c}384 \\
(52,94 \%)\end{array}$ \\
\hline
\end{tabular}

Bron: Navorser se samevatting

* Ingesluit e-posse aan alle paneellede in Fase 2 van die navorsingsprojek.

** Daar is nie van respondente wat in die eerste twee fases van die navorsingsprojek deelgeneem het verwag om weer in die derde fase van die proses deel te neem nie. Daar was egter gevalle waar die respondente gevoel het hulle wou ook hulle stem uitbring in hierdie fase van die navorsingsprojek. *** \% van die aantal e-posse gestuur op grond van die potensiële populasie.

Indien die positiewe response op alle e-posse bereken word, dui dit ' $n$ baie swak responskoers van 39,33\% aan. Soos gesien kan word in TABEL 2 is die meer reële responskoers $44,64 \%$.

\section{Data-ontleding}

\subsection{Datavoorbereiding}

Nadat die primêre data deur middel van die aanlyn vraelys ingesamel is, was die volgende stap in die navorsingsproses die voorbereiding en ontleding daarvan. Data-analise kan eers begin nadat die onbewerkte ("rou") data verwerk en in 'n geskikte (elektroniese) formaat omgeskakel is. In navorsing is dit bekend dat noukeurige datavoorbereiding die kwaliteit van die bevindings kan verbeter en tot beter besluite kan lei (Hair, Black, Babin \& Anderson, 2010; Malhotra, 2002).

Alle vraelyste is elektronies met behulp van aanlyn sagteware (Google Forms) geadministreer. Data wat deur die vraelys bekom is, is direk in 'n aparte aanlyn leer (Google Sheets) 
gestoor. Data is toe onttrek en in 'n MS Excel-werkboek gestoor vir verdere ontleding. Vir meer gevorderde analise is daar van SPSS ${ }^{\circledR}$ 26-sagteware gebruik gemaak.

Die eerste stap in die voorbereiding van die data was om te kyk of dit volledig is (Zikmund et al., 2013). In die vraelys was slegs sekere van die vrae verpligtend en daarom kon onvolledige antwoorde soms deur respondente ingedien word. Benewens volledigheid, moes die vraelys ook hersien word om akkuraatheid te bevestig en te verhoog (Malhotra, 2002). 'n Respondent het byvoorbeeld in die beantwoording van die vraelys per ongeluk sy/haar geboorte jaar as "1872" aangedui - dit kon duidelik nie die geval wees nie en die navorser het dus dit toe na “1972” verander.

\subsection{Data-analise}

Nadat die data-voorbereiding voltooi is, het die data-analise geskied. Die primêre doel van data-analise was om betekenis aan die data te gee. Ali en Bhaskar (2016: 662) het data-analise beskryf as "breathing life into lifeless data". Beskrywende en afgeleide ontleding is op alle data gedoen deur gebruik te maak van MS Excel en SPSS ${ }^{2} 26$ sagteware.

Data is ontleed deur eerstens belangrike beskrywende statistiek te verskaf voordat daar verslag gelewer word oor die keuse van respondente se gunstelingkerklied.

\section{Demografiese inligting}

FIGUUR 3 dui die ouderdomsverspreiding van respondente aan. Die meetkundige gemiddelde ouderdom is 57,19 jaar $(\mathrm{SD}=13,78)$.



Figuur 3: $\quad$ Ouderdomsverspreiding van respondente

Bron: SPSS 26 
Vroulike respondente het 'n gemiddelde ouderdom van 57,75 jaar in vergelyking met die mans op 56,53 jaar. Uit opmerkings uit die vraelys is dit duidelik dat ouderdom dalk 'n invloed kan/ sal hê op die keuse van liedere:

"Nogal moeilik om te kies ... ek is van mening dat geliefde liedere varieer afhangende van ouderdomsgroep en godsdienstige en selfs kulturele agtergrond." [Respondent FIN037]

“Dis baie moeilik om namens kinders te besluit ...” [Respondent_FIN059]

FIGUUR 4 dui die verspreiding van respondente per provinsie aan.

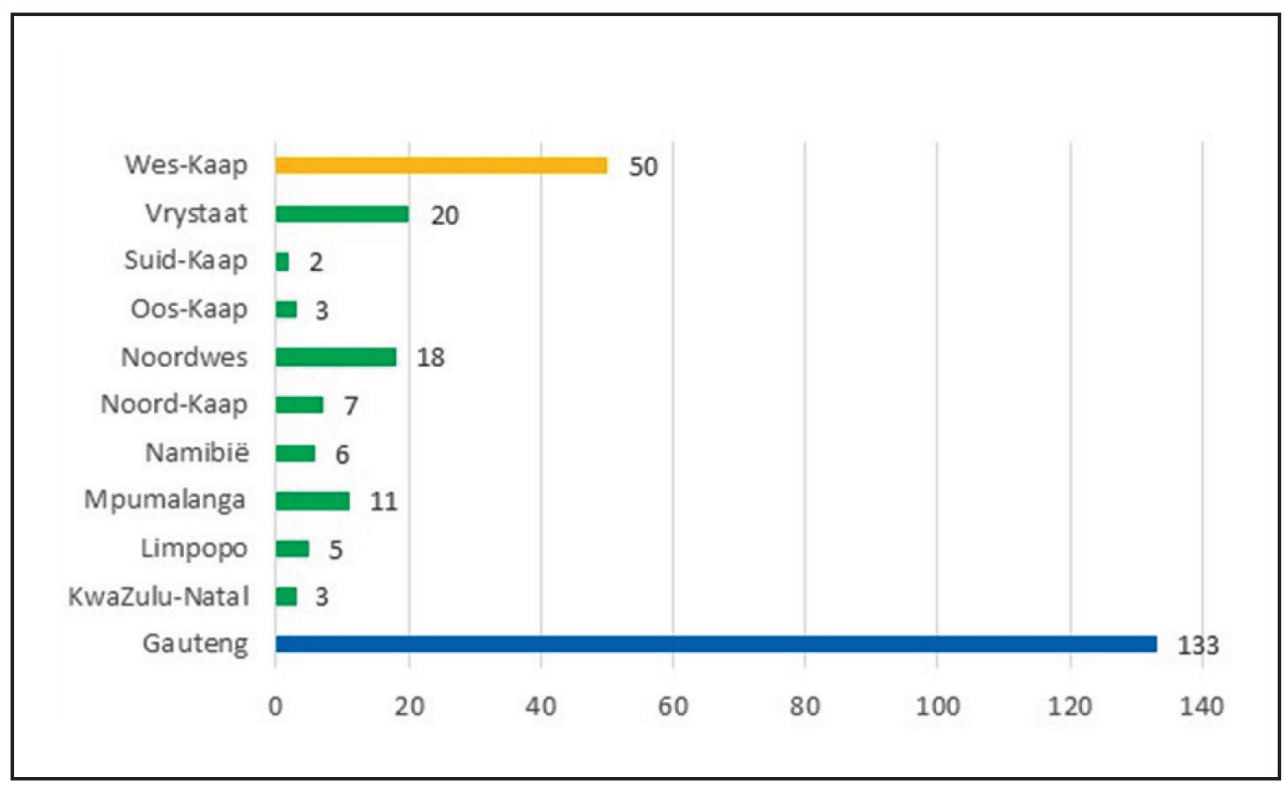

Figuur 4: $\quad$ Provinsiale verspreiding van respondente

Bron: SPSS 26

Uit die 258 respondente het 51,6\% uit Gauteng gekom met die Wes-Kaap wat vir 19,4\% van die respondente gesorg het.

FIGUUR 5 dui die persentasie verspreiding van respondente volgens geslag per provinsie aan. 




Figuur 5: $\quad$ Persentasie provinsiale verspreiding van respondente volgens geslag Bron: SPSS 26

Al drie die respondente uit KwaZulu-Natal was vroulik.

TABELLE 3 en 4 dui die verspreiding van respondente volgens hul huidige rol in hul gemeentes aan asook die aantal jare wat respondente in hierdie rolle in hul gemeentes betrokke is.

TABEL 3: Huidige rol of betrokkenheid by die respondent se gemeente

\begin{tabular}{|l|c|c|c|}
\hline & $\begin{array}{c}\text { Manlik } \\
(\mathbf{n = 1 1 8 ;} \\
\mathbf{4 5 , 7 4 \% )}\end{array}$ & $\begin{array}{c}\text { Vroulik } \\
\mathbf{( n = 1 4 0 ;} \\
\mathbf{5 4 , 2 6 \% )}\end{array}$ & $\begin{array}{c}\text { TOTAAL } \\
(\mathbf{n}=\mathbf{2 5 8})\end{array}$ \\
\hline $\begin{array}{l}\text { Ek is 'n administratiewe beampte/ander werknemer in } \\
\text { die gemeente }\end{array}$ & 1 & 3 & 4 \\
\hline Ek is 'n emeritus leraar/pastorale hulp & 3 & 0 & 3 \\
\hline Ek is 'n afgetrede orrelis & 0 & 1 & 1 \\
\hline Ek is 'n aflos-orrelis/pianis & 6 & 5 & 11 \\
\hline Ek is 'n besoeker in die gemeente & 1 & 3 & 4 \\
\hline Ek is 'n lidmaat van die gemeente & 38 & 45 & 83 \\
\hline Ek is die leraar van die gemeente & 22 & 2 & 24 \\
\hline Ek is die musiekleier/-direkteur van die gemeente & 1 & 1 & 2 \\
\hline $\begin{array}{l}\text { Ek is die musiekleier/-direkteur asook die orrelis/pianis van } \\
\text { die gemeente }\end{array}$ & 8 & 17 & 25 \\
\hline Ek is die orrelis van die gemeente & 30 & 53 & 83 \\
\hline $\begin{array}{l}\text { Ek is lid van die informele sanggroep/koor/kantory in die } \\
\text { gemeente }\end{array}$ & 5 & 7 & 12 \\
\hline $\begin{array}{l}\text { Ek is lid van die instrumentale begeleidingsgroep (band) van } \\
\text { die gemeente }\end{array}$ & 1 & 3 & 4 \\
\hline Ek is nie enigsins betrokke by 'n gemeente nie & 2 & 0 & 2 \\
\hline
\end{tabular}

Bron: Navorser se samevatting, SPSS 26 
TABEL 4: Aantal jare betrokke in die rol in die respondent se gemeente

\begin{tabular}{|l|c|c|c|}
\hline & Manlik & Vroulik & TOTAAL \\
\hline$<=0$ jaar & 1 & 0 & 1 \\
\hline $1-10$ jaar & 43 & 63 & 106 \\
\hline $11-21$ jaar & 27 & 30 & 57 \\
\hline $22-31$ jaar & 23 & 20 & 43 \\
\hline $32-41$ jaar & 15 & 18 & 33 \\
\hline $42-51$ jaar & 4 & 6 & 10 \\
\hline $52-62$ jaar & 5 & 1 & 6 \\
\hline $63+$ jaar & 0 & 2 & 2 \\
\hline
\end{tabular}

Bron: Navorser se samevatting, SPSS 26

Die modale lengte van betrokkenheid volgens bostaande tabel is tussen 1 en 10 jaar.

FIGURE 6a en 6b dui die verspreiding van respondente volgens hul kerkverband aan. FIGUUR 6a toon die geslagsverspreiding van respondente merendeels volgens die drie Susterskerke aan.

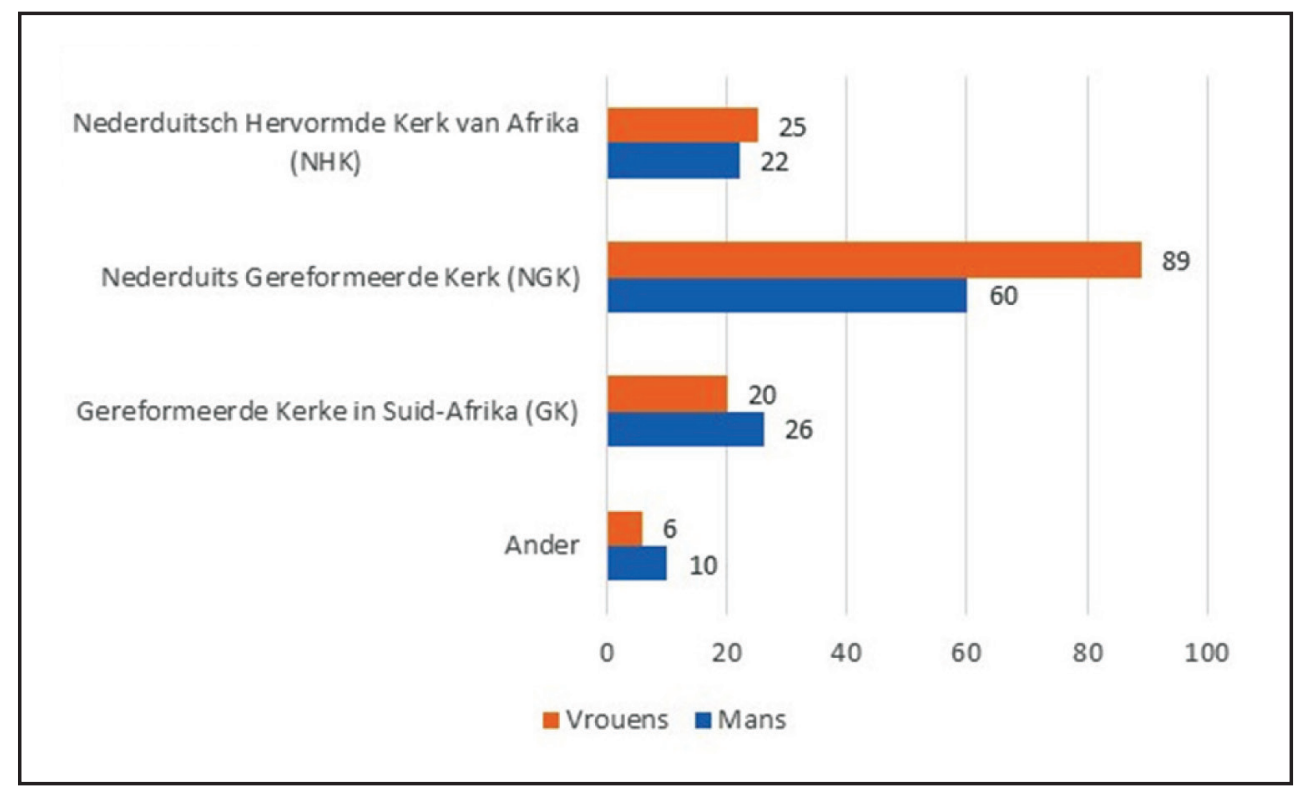

Figuur 6a: Verspreiding van respondente volgens kerkverband (1)

Bron: SPSS 26

FIGUUR 6b toon die verspreiding van die groep "Ander" in meer detail aan. 


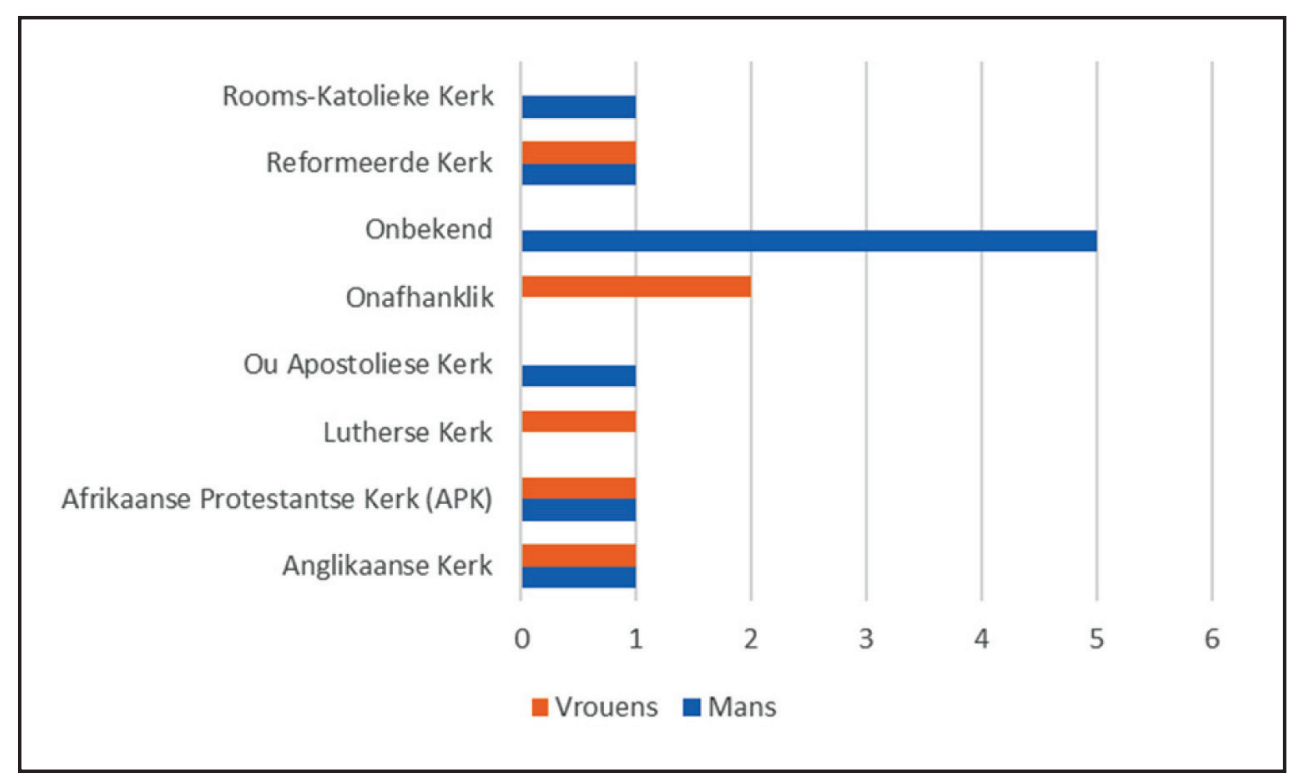

Figuur 6b: Verspreiding van respondente volgens "Ander" kerkverband (2) Bron: SPSS 26

\section{Keuse van gunstelingliedere}

In die bepaling van die onderskeie gunstelingliedere moes die navorser duidelikheid kry oor die statistiese toetse wat hy sou gebruik ten einde die finale uitslag te kon bepaal. Die navorser kon nie net deur middel van die berekening van die rekenkundige gemiddelde waarde 'n besluit neem nie omdat response in die vorm van rangordes was. Daar is toe op die beginsel van multikriteria-besluitneming besluit. Multikriteria-besluitneming verwys na die prioritisering of rangskikking van alternatiewe gebaseer op menslike oordeel uit 'n eindige stel alternatiewe ten opsigte van meervoudige, gewoonlik botsende kriteria (Roszkowska, 2013).

Die eenvoudige en mees gebruikte multikriteria-besluitnemingstegniek is die Eenvoudige Additiewe Gewigstegniek (Simple Additive Weighting $(S A W)$ ), ook bekend as geweegde lineêre kombinasie-metode. Hierdie metode is gebaseer op geweegde gemiddelde (Roszkowska, 2013).

In SAW-tegniek word die finale waarde van elke alternatief soos volg bereken:

$$
S_{i}=\sum_{j=1}^{n} c_{i j} w_{j}
$$

waar:

$\mathrm{S}_{i}$ is die waarde vir die $i$-de alternatief;

$\mathrm{c}_{i j}$ is die genormaliseerde waarde van die $i$-de alternatief met betrekking tot die $j$-de kriterium; en

$\mathrm{w}_{\mathrm{j}}$ is die gewig van kriteria $j$. 
Vervolgens word die finale rangordewaardes gerangskik wat impliseer dat hoe hoër die waarde van $\mathrm{S}_{i}$ is, hoe hoër is die rang.

In die vraelys het respondente byvoorbeeld 'n lys van nege liedere uit een van die bronne gekry. Hulle moes dan die nege liedere in 'n rangorde rangskik, van die mees geliefde tot die een waarvan hulle die minste hou. Die finale keuse van liedere is dus gegrond op die produk van geweegde rangordes.

Die volgende figure dui die uitslag van die keuse van die finale Top-10 gunstelingkerkliedere volgens bron aan omdat nie alle respondente vir liedere vanuit al die bronne gestem het nie.

\section{- Psalms}



Figuur 7: $\quad$ TOP-10 Psalms volgens rangordekeuse (respondente $\bar{x}=146$ )

Bron: SPSS 26

FIGUUR 7 dui die Top-10 Psalms volgens rangordekeuse aan. Respondente het 'n keuse van 10 Psalms gehad waaruit hulle ses in rangorde kon plaas. Sowat $68,45 \%$ van al die rangordekeuses is uitgebring vir die liedere in die eerste vyf posisies. Nie eers 'n volle persentasiepunt (0,30\%) skei die liedere in die eerste twee posisies nie. Psalm 33 (Sing juigend, sing 'n nuwe loflied) en Psalm 146 (Prys die Here, loof en prys Hom) is onderskeidelik deur 194 en 188 respondente gekies - die tweede en derde meeste respondente wat vir enige lied in die steekproef gestem het.

Uit die respons was dit duidelik dat die Psalms nog steeds 'n rol in gemeentesang speel. Wat ook uitgekom het in die kommentaar van sommige respondente is die belangrikheid van die ou Totius-Psalms vir sekere lidmate.

“... van die liedere is nie so bekend aan my ... ons het meesal in Geref Kerk net ou Psalms gesing ..." [Respondent_FIN050] 
"Ek kon nie al die keuses uitoefen nie omdat ons in die Gereformeerde Kerk konserwatief hou by Psalms, Skrifberymings en enkele liedere uit die Liedboek ...” [Respondent_ FIN047]

"Die TT Cloete berymings se woorde bly onbekend omdat psalms selde gesing word. Prof. Willie Jonker het gesê dat dit 'n wesenskenmerk van 'n gereformeerde kerk is om psalms te sing." [Respondent_FIN148]

"Was dit nodig om liedere se woorde in Liedboek bv. Psalm 42 so te verander?" [Respondent_FIN038]

"[***] Geref. kerk sing slegs Totius-berymings. Wat die gesange betref is dit vanselfsprekend my persoonlike keuse. Ekself lei die vooraf-sang en aanleer van minder bekende Psalms." [Respondent_FIN082]

\section{- Gesange/Liedboekliedere}

In die geval van Gesange/Liedboekliedere kon respondente 'n rangordekeuse van twee groepe van sewe liedere elk uit 25 moontlike liedere mak.



Figuur 8: $\quad$ TOP-10 Gesange/Liedboekliedere volgens rangordekeuse (respondente $\bar{x}=$ 106)

Bron: SPSS 26

FIGUUR 8 dui die Top-10 Gesange/Liedboekliedere volgens rangordekeuse aan. Sowat $80,23 \%(n=207)$ van die respondente het vir Gesang/Liedboeklied 266 (Ons Vader wat woon in die hemel) gestem. Dit was ook die lied wat deur die meeste respondente in hul rangordekeuses gekies is. Nie eers 0,09 persentasiepunte skei die liedere in die agtste, negende en tiende posisies nie (Gesang/Liedboeklied 190 - Grote God, aan U die eer; Gesang/Liedboeklied 
169 - Heilig, heilig, heilig, Heer God almagtig; en Gesang/Liedboeklied 200 - U goedheid, Heer, kan ons nie peil nie).

Indien die rangordekeuses van al die kerkliedere in die steekproef tesame ontleed word, dan sien mens dat dit Gesange/Liedboekliedere is wat die eerste drie posisies hier beklee (266 - Ons Vader wat woon in die hemel; 280 - Here, Redder, groot en magtig - ook Gesang/ Liedboeklied 281; en 464 - O Heer my God - ook Gesang/Liedboeklied 516 en Skrifberyming 14-2). Hierdie liedere word ook beskou as die top-drie-kerkliedere uit al vier die bronne uit.

Van die kommentaar oor die Gesange/Liedboekliedere in die steekproef het onder andere die volgende gesê:

"Al die [liedboek]-liedere wat in kolomme verdeel is vir die projek word gereeld in ons gemeente gesing. Ek sou by almal as ek kon geplaas het as le keuse." [Respondent FIN019]

"Ek wens net dat gemeentes die wonderlike, baie bruikbare Liedboekliedere sal gebruik en nie slegs die "top 20's" nie!" [Respondent_FIN066]

\section{- VONKK-liedere}

FIGUUR 9 dui die Top-10 VONKK-liedere volgens rangordekeuse aan. In die geval van VONKK-liedere kon respondente 'n rangordekeuse van twee groepe van ses liedere elk uit 22 moontlike liedere maak.

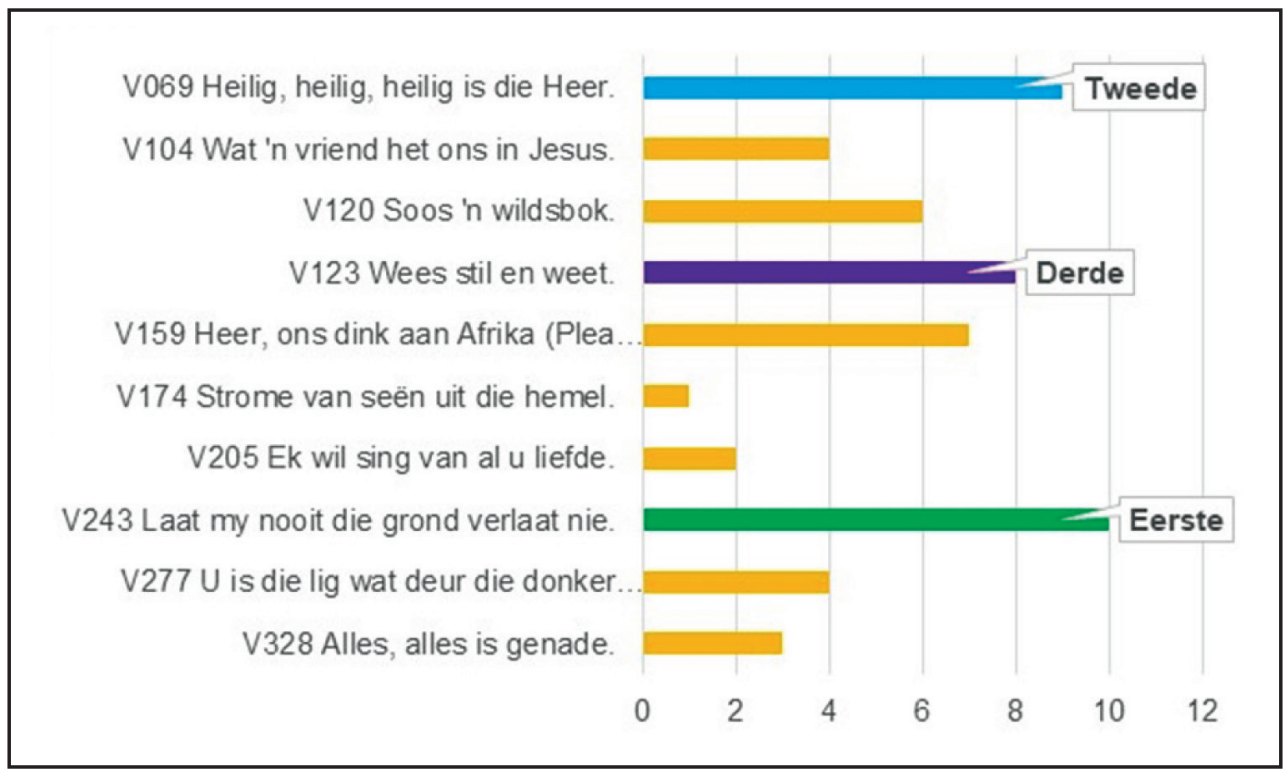

Figuur 9: $\quad$ TOP-10 VONKK-liedere volgens rangordekeuse (respondente $\bar{x}=138$ ) Bron: SPSS 26

Net sowat 1,45 persentasiepunte skei die eerste twee liedere in die groep $(8,39 \%$ en $6,95 \%)$. 
“Ons sing ook baie VONKK-liedere-meer as die FLAM-liedere” [Respondent_FIN019]

- FLAM-liedere

FIGUUR 10 dui die Top-10 FLAM-liedere volgens rangordekeuse aan. In die keuse van FLAM-liedere kon respondente 'n rangordekeuse van twee groepe van ses liedere elk uit 19 moontlike liedere maak.

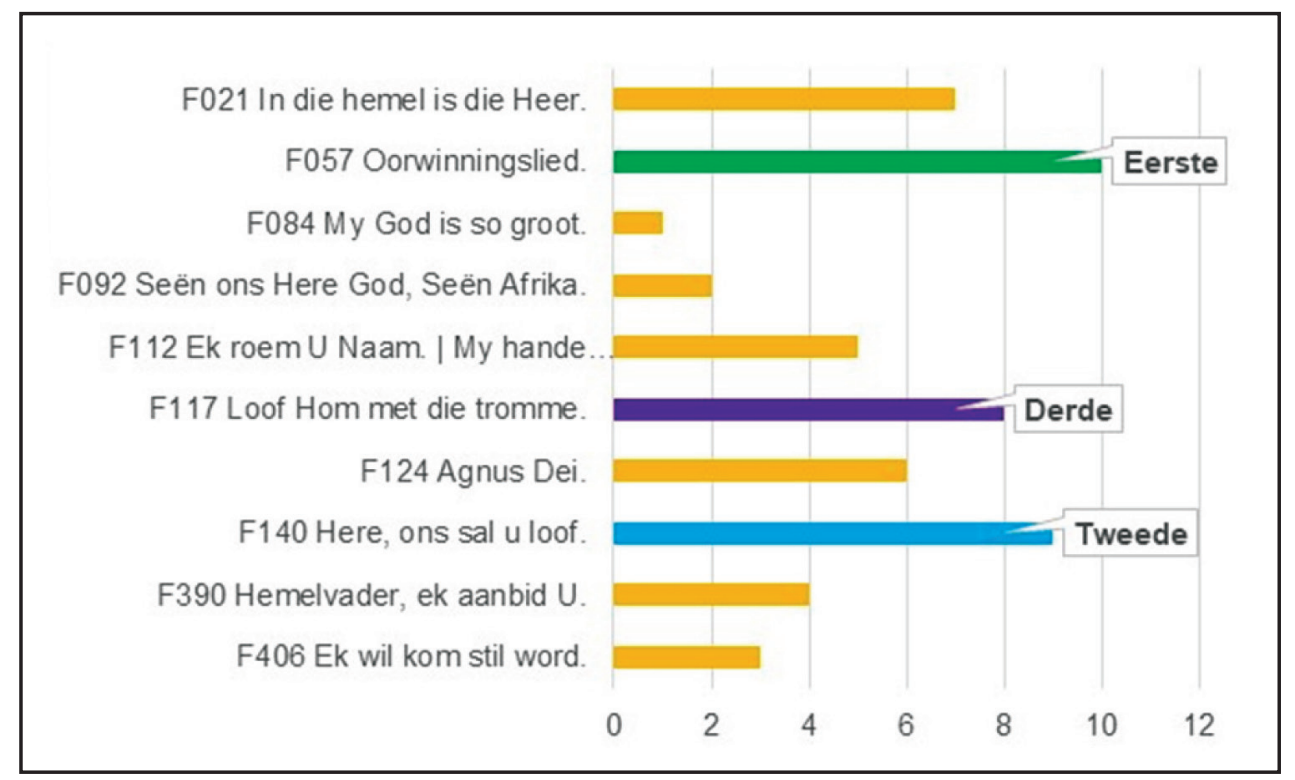

Figuur 10: “TOP-10” FLAM-liedere volgens rangordekeuse (respondente $\bar{x}=136$ ) Bron: SPSS 26

Sowat 3,28 persentasiepunte skei die eerste twee liedere in die groep (10,50\% en 7,30\%). In die geval van FLAM 057 (Oorwinningslied) het 67,44\% $(n=174)$ van die respondente vir die lied gestem.

Van die kommentaar oor die VONKK- en FLAM-liedere in die steekproef was onder andere:

“Ek kan nie 'n keuse uitoefen oor FLAM liedere nie ...” [Respondent_FIN094]

"Ek wens dat FLAM- en VONKK-liedere makliker toeganklik sal wees. Alhoewel gemeentes meer van die liedere sou wou sing, is registrasie- sowel as jaarlikse fooie buitensporig hoog om die liedere te bekom." [Respondent_FIN029]

“[*** gemeente] ken feitlik geen VONKK- of FLAM-liedere nie. [Ons] konsentreer slegs op Liedboek-groot weerstand teen aanleer van nuwe liedere.”[Respondent_FIN186]

"Die afwesigheid van antwoorde oor VONKK- en FLAM-voorkeure is omdat ons gemeente, die enigste Geref Kerk gemeente in [***] glad nie ooit uit hierdie bundels sing nie en wanneer ek by verskeie gemeentes in [***] as orrelis aflos is dit ook net liedere uit die 
Liedboek wat gebruik word. Daar word wel in die NG gemeentes van VONKK en FLAM gebruik gemaak, maar daar word nêrens verwag dat die aflos-orrelis saam met 'n begeleidingsgroep moet speel nie. Ook in die enigste Herv Gemeente in [***] word slegs uit Liedboek gesing. ” [Respondent_FIN197]

Een van die respondente het die volgende opmerking in sy/haar vraelys gemaak:

"COVID-19 het gemaak dat ons nie kon sing in die eredienste [nie]. Ons het op YouTube na hierdie gewilde liedere gesoek en dit op Sondae met die gemeente gedeel. Deur stil te luister bring ook nuwe impak en dikwels het lidmate opgemerk dat hulle nou weer nuut na die inhoud van die liedere kyk." [Respondent_FIN052]

TABEL 5 verskaf 'n samevatting van die begeleidingsmodusse in die onderskeie gemeentes van die respondente.

TABEL 5: Samevatting van die begeleidingsmodusse in die onderskeie gemeentes

\begin{tabular}{|l|c|}
\hline $\begin{array}{l}\text { Gemeentesang word afwisselend deur die klavier/klawerbord en die } \\
\text { instrumentale begeleidingsgroep ( } \text { band) begelei. }\end{array}$ & 1 \\
\hline $\begin{array}{l}\text { Gemeentesang word afwisselend deur die orrel en die instrumentale begelei- } \\
\text { dingsgroep ( } \text { band) begelei. }\end{array}$ & 17 \\
\hline Gemeentesang word afwisselend deur die orrel en die klavier begelei. & 26 \\
\hline Gemeentesang word afwisselend deur die orrel en opnames van liedere begelei. & 3 \\
\hline $\begin{array}{l}\text { Gemeentesang word afwisselend deur die orrel, klavier/klawerbord en die } \\
\text { instrumentale begeleidingsgroep ( } \text { band) begelei. }\end{array}$ & 16 \\
\hline Gemeentesang word deur die instrumentale begeleidingsgroep (band) begelei. & 5 \\
\hline Gemeentesang word deur die klavier/klawerbord begelei. & 5 \\
\hline Gemeentesang word deur die orrel begelei. & 142 \\
\hline Gemeentesang word deur die orrel met ander instrumente begelei. & 1 \\
\hline Gemeentesang word deur opnames van liedere begelei. & 3 \\
\hline $\begin{array}{l}\text { Gemeentesang word in kombinasie deur die klavier/klawerbord en die } \\
\text { instrumentale begeleidingsgroep (band) begelei. }\end{array}$ & 11 \\
\hline $\begin{array}{l}\text { Gemeentesang word in kombinasie deur die orrel en die instrumentale } \\
\text { begeleidingsgroep (band) begelei. }\end{array}$ & 9 \\
\hline Gemeentesang word in kombinasie deur die orrel en die klavier begelei. & 7 \\
\hline $\begin{array}{l}\text { Gemeentesang word in kombinasie deur die orrel, klavier/klawerbord en die } \\
\text { instrumentale begeleidingsgroep (band) begelei. }\end{array}$ & 10 \\
\hline Onbekend & 2 \\
\hline Totaal & $\mathbf{2 5 8}$ \\
\hline
\end{tabular}

Bron: Navorser se samevatting, SPSS 26

Uit die tabel is dit duidelik dat die mees gebruikte begeleidingsmodus nog steeds die orrel is $(55,04 \%)$ gevolg deur afwisselende begeleiding deur orrel en klavier $(10,08 \%)$.

Van die respondente het die volgende opmerkings spesifiek oor die gebruik van die orrel gemaak:

"Ek persoonlik is nie 'n voorstander van die gebruik van voorsangers nie. Ek beleef dat gemeentelede dan minder deelneem. Dieselfde geld natuurlik vir 'n begeleidingsgroep 
wat te hard speel. In laasgenoemde geval ontaard dit meesal in 'n vertoning. Die orrel bly steeds die beste instrument om gemeentesang te inspireer en te ondersteun!" [Respondent_FIN025]

“'n Goeie orrelis maak vir seker die verskil of 'n gemeente goed of sleg sing ..." [Respondent_FIN001]

"In 'n gemeente waar daar ouer lidmate, maar ook jonger lidmate is, werk dit baie goed om tradisionele orrelbegeleiding te gebruik en af te wissel met klavier en orkesbegeleiding. My ervaring is dat die meer moderne FLAM- en VONKK-liedere net so gemaklik op die orrel gespeel kan word, as met 'n orkes, en dat die orrel dan steeds die gewyde stemming bring wat deur die ouer lidmate verkies word. Die jonger lidmate geniet die FLAM- en VONKK-liedere, ook met orrelbegeleiding, mits die orrelis 'buigbaar' is ten opsigte van die begeleiding." [Respondent_FIN192]

\section{Samevatting}

Die doel van hierdie artikel was om op navorsingsmatige wyse terugvoer te gee oor die keuse van respondente se gunstelingkerklied in Afrikaanssprekende gemeentes in Suider-Afrika. Die navorsingsproses (as deel van Fases 1 en 2 van die navorsingsprojek) in die daarstelling van 'n konsensussteekproef wat deur respondente gebruik is, is alreeds in 'n ander artikel volledig bespreek. In hierdie artikel is daar net gefokus op die ontleding van data in die derde fase van die navorsingsprojek.

Om deur middel van die navorsing te bepaal watter kerkliedere lidmate in Afrikaanssprekende gemeentes se gunstelinge is, het die navorser gebruik gemaak van die bekendste bronne van kerkliedere wat ingesluit het die Liedboek van die Kerk (2001); die Psalmboek (2003); VONKK-liedere (2020); en FLAM-liedere (2020).

$\mathrm{Na}$ aanleiding van die eerste twee fases van die navorsingsprojek is daar 'n konsensussteekproef van kerkliedere bepaal wat die navorser dan gebruik het in hierdie derde fase van die navorsingsprojek.

In hierdie fase van die navorsingsprojek is daar van respondente verwag om 'n opname in die vorm van 'n aanlyn vraelys te voltooi wat bestaan het uit oop en geslote vrae. Daar was ook 'n afdeling waar hulle hul rangordekeuses met betrekking tot hul gunstelingkerkliedere kon uitoefen waar daar van 'n ordinale metingskaal gebruik gemaak is. Aangesien deelname aan die navorsingsprojek vrywillig was en die waarskynlikheid dat 'n lid van die teikenpopulasie gereageer het, onbekend was, is daar van nie-waarskynlikheidsteekproefneming in die navorsing gebruik gemaak.

Vroulike respondente met 'n gemiddelde ouderdom van 57,75 jaar was die grootste deel van die steekproef respondente. Sowat 133 respondente het uit die Gauteng provinsie gekom waarvan die meeste (83 elk) lidmate en orreliste in hul onderskeie gemeentes is. Ander belangrike rolle wat respondente in hul onderskeie gemeentes vervul het, was dié van musiekleier/-direkteur asook die orrelis/pianis van die gemeente (25) en ook die gemeenteleraar (24). Die grootste gros van respondente (147) het vanuit die Nederduits Gereformeerde Kerk gekom.

In die bepaling van die mees geliefde kerklied moes respondente hul gunstelingliedere in 'n rangorde van keuse plaas. Die finale keuse van liedere was dus gegrond op die produk van geweegde rangordes. 
Indien al die keuses van respondente in 'n gesamentlike rangorde geplaas word, sien die finale lys van die top-10 gunstelingliedere soos volg uit: (1) Gesang 266 - Ons Vader wat woon in die hemel; (2) Gesang 280 - Here, Redder, groot en magtig; (3) Gesang 464 - O Heer my God; (4) FLAM 57 - Oorwinningslied; (5) Psalm 33 - Sing juigend, sing 'n nuwe loflied; (6) Psalm 146 - Prys die Here, loof en prys Hom; (7) VONKK 243 - Laat my nooit die grond verlaat nie; (8) Gesang 284 - Laat, Heer, U vrede deur my vloei; (9) Gesang 509 - Op berge en in dale; en (10) Gesang 510 - Genade, onbeskryflik groot.

Uit die kommentaar wat vanuit die vraelyste gekom het, was dit duidelik dat hierdie projek om die mees geliefde kerklied in Afrikaanssprekende gemeentes te bepaal, werklik 'n debat onder lidmate ontketen het.

Die navorser gaan poog om resultate van die algehele navorsingsproses by verskeie streeksvergaderings van SAKOV met lede te deel.

\section{BIBLIOGRAFIE}

Ali, Z \& Bhaskar, SB. 2016. Basic statistical tools in research and data analysis. Indian Journal of Anaesthesia, 60(9):662-669.

Barr, A. 2006. About Songs of Praise - Past and Present. http://www.bbc.co.uk/songsofpraise/about. shtml. [24 Februarie 2021].

BBC. 2013. The UK's Top 100 Hymns - The Songs of Praise Big Sing. https://www.bbc.co.uk/programmes/ articles/42TSJ0LNMfp0h0wNvxqlw93/2013-the-uks-top-100-hymns. [24 Februarie 2021].

British Period Dramas. 2019. The UK's favourite hymn has been revealed on 'Songs of Praise'. https:// britishperioddramas.com/news/uks-favourite-hymn-revealed-songs-of-praise-2019/. [24 Februarie 2021].

Blumenberg, C, Menezes, AMB, Gonçalves, H, Wehrmeister, MC \& Barros, FC. 2019. The role of questionnaire length and reminders frequency on response rates to a web-based epidemiologic study: a randomised trial. International Journal of Social Research Methodology, 22(6):625-635. https://10.1080/13645579.2019.1629755. [4 Maart 2021].

Collis, J \& Hussey, R. 2009. Business Research: A Practical Guide for Undergraduate and Postgraduate Students, $3^{\text {rd }}$ ed. New York, NY: Palgrave Macmillan.

Couper, MP, Kapteyn, A, Schonlau, M \& Winter, J. 2007. Noncoverage and nonresponse in an internet survey. Social Science Research, 36(1):131-148.

Denscombe, M. 2009. Item non-response rates: A comparison of online and paper questionnaires. International Journal of Social Research Methodology, 12(4):281-291.

Dodge, N \& Chapman, R. 2018. Investigating recruitment and completion mode biases in online and door to door electronic surveys. International Journal of Social Research Methodology, 21(2):149163.

Els, G. 2020. Die gebruik van die Delphi-tegniek in die bepaling van ons mees geliefde Kerklied: 'n Metodiese oorsig. Vir die MUSIEKLEIER/To the DIRECTOR of MUSIC, 40(47):50-76.

Fan, W \& Yan, Z. 2010. Factors affecting response rates of the web survey: A systematic review. Computers in Human Behavior, 26(2):132-139.

FLAM. 2020. Aanlyn beskikbaar: http://flam.co.za.

Granello, DH \& Wheaton, JE. 2004. Online data collection: Strategies for research. Journal of Counseling \& Development, 82(4):387-393.

Hair, JF, Black, WC, Babin, BJ \& Anderson, RE. 2010. Multivariate Data Analysis, $7^{\text {th }}$ ed. Prentice Hall, Upper Saddle River, New Jersey.

Heerwegh, D \& Loosveldt, G. 2008. Face-to-face versus web surveying in a high-internet-coverage population differences in response quality. Public Opinion Quarterly, 72(5):836-846.

Heyns, C. 1988. Wat skort met ons kerkmusiek? Vir die Musiekleier, 8:19-28.

Hirschhorn, F. 2019. Reflections on the application of the Delphi method: lessons from a case in public transport research. International Journal of Social Research Methodology, 22(3):309-322. https:// doi.org/10.1080/13645579.2018.1543841. 
Höhne, JK \& Krebs, D. 2018. Scale direction effects in agree/disagree and item-specific questions: a comparison of question formats. International Journal of Social Research Methodology, 21(1):91103. https://doi.org/10.1080/13645579.2017.1325566. [4 Maart 2021].

Hollingworth, HL. 1913. Characteristic Differences between Recall and Recognition. The American Journal of Psychology, 24(4):532-544.

Jacobs, L. 1995. An on-line faculty evaluation system: Development, use, and research. Paper presented in April 1995 at the annual meetings of the American Educational Research Association, San Francisco, CA.

Johnson, EP, Siluk, L \& Tarraf, S. 2014. Techniques for fusing survey modules: Respondent matching and data imputation. International Journal of Market Research, 56(4):425-442. DOI: $10.2501 /$ IJMR-2014-031.

Justice, D. 2010. Public, Private; Contemporary, Traditional: Intersecting Dichotomies and Contested Agency in Mainline Protestant Worship Music. Folklore Forum, April 2020:24-41.

Kampen, JK. 2019. Reflections on and test of the metrological properties of summated rating, Likert, and other scales based on sums of ordinal variables. Measurement, 137:428-434. https://doi. org/10.1016/j.measurement.2019.01.083. [1 Maart 2021].

Keeney, S, Hasson, F \& Mckenna, HP. 2001. A critical review of the Delphi technique as a research methodology for nursing. International Journal of Nursing Studies, 38:195-200.

Kloppers, EC. 2003. Vernuwing in die Kerklied: Die Liedboek van die Kerk (2001). Acta Theologica, 1:71-82.

Korenman, L \& Peynircioglu, Z. 2007. Individual differences in learning and remembering music: auditory versus visual presentation. Journal of Research in Music Education, 55:48-59.

Kraut, R. 1984. Telecommuting: Cautious pessimism. Murray Hill, NJ: Bell Communications Research.

Kruger, D. 2007. "A high degree of understanding and tolerance": Veranderende denke oor die moderne gereformeerde kerklied. Koers, 72(4):649-669.

Krumpal, I. 2013. Determinants of social desirability bias in sensitive surveys: A literature review. Quality \& Quantity, 47(4):2025-2047.

Lamm, AJ \& Lamm, KW. 2019. Using Non-Probability Sampling Methods in Agricultural and Extension Education Research. Journal of International Agricultural and Extension Education, 26(1):52-59. https://doi: 10.5191/jiaee.2019.26105. [1 Maart 2021].

Liedboek. 2001. Liedboek van die Kerk vir gebruik by die erediens en ander byeenkomste. Kaapstad: NG Kerk-uitgewers.

MacLachlan, S. 2009. Memory for the recall of popular songs: a comparative study of musicians and nonmusicians. Perth: Edith Cowan University. Unpublished thesis. https://ro.ecu.edu.au/theses hons/1107. [15 Januarie 2021].

Malhotra, NK. 2002. Basic Marketing Research Applications to Contemporary Issues. Upper Saddle River, NJ: Prentice Hall.

NAC Today. 2017. A new Afrikaans hymnal. https://nac.today/en/a/503608. [20 November 2020].

Norman, KL, Friedman, Z, Norman, K \& Stevenson, R. 2001. Navigational issues in the design of online self-administered questionnaires. Behaviour \& Information Technology, 20(1):37-45.

Papenfus, AF. 1994. 'n Waardebepaling van die nie-amptelike, informele kerklied soos gesing in die erediens in gemeentes van die Nederduitse Gereformeerde Kerk in die PWV. Ongepubliseerde MMus-verhandeling. Pretoria: UNISA.

Paudel, KP, Poudel, BN, Dunn, MA \& Pandit, M. 2009. An Analysis of Rank Ordered Data. Paper presented at the Agricultural \& Applied Economics Association's 2009 AAEA \& ACCI Joint Annual Meeting, Milwaukee, WI, July 26-28, 2009.

Peretz, I, Gaudreau, D \& Bonnel, A. 1998. Exposure effects on music preference and recognition. Memory \& Cognition, 26(5):884-902.

Psalmboek. 2003. Die berymde en omgedigte Psalms en ander Skrifberyminge in die gebruik by die Gereformeerde Kerke in Suid-Afrika. Wellington: NG Kerk-Uitgewers.

Roszkowska, E. 2013. Rank Ordering Criteria Weighting Methods - A Comparative Overview. Optimum. Economic Studies, 5(65):14-33. DOI: 10.15290/ose.2013.05.65.02.

Rowe, G \& Wright, G. 1999. The Delphi technique as a forecasting tool: Issues and analysis. International Journal of Forecasting, 15(4):353-375. 
Sekayi, D \& Kennedy, A. 2017. Qualitative Delphi Method: A Four Round Process with a Worked Example. The Qualitative Report, 22(10):2755-2763.

Shermis, MD \& Lombard, D. 1999. A Comparison of Survey Data Collected by Regular Mail and Electronic Mail Questionnaires. Journal of Business and Psychology, 14(2):341-354.

Shoemaker, PJ, Eichholz, M \& Skewes, EA. 2002. Item Nonresponse: Distinguishing between Don't Know and Refuse. International Journal of Public Opinion Research, 14(2):193-201.

Skulmoski, GJ, Hartman, FT \& Krahn, J. 2007. The Delphi Method for Graduate Research. Journal of Information Technology Education, 6:1-21.

Sproull, LS. 1986. Using electronic mail for data collection in organizational research. Academy of Management Journal, 29(1):159-169.

Temmingh, R. 1993. Kerkmusiek in krisis. Vir die Musiekleier, 13:17-19.

Tourangeau, R, Conrad, FG \& Couper, MP. 2013. The Science of Web Surveys. New York, NY: Oxford University Press.

Troskie, A. 1992. Tot hier toe en nie verder met ons kerkmusiek. Vir die Musiekleier, 12:46.

Van der Merwe, J. 1995. "Kitsch" in die kerk? - oor vernuwing en vervlakking in ons Kerkmusiek. Vir die Musiekleier, 15:4-10.

Viljoen, AM. 2006. Die waarde en funksie van liturgiese musiek. Dutch Reformed Theological Journal / Nederduitse Gereformeerde Teologiese Tydskrif, 47(3 \& 4):760-772.

VONKK (Voortgesette Ontwikkeling van Nuwe Klassieke Kerkmusiek). 2020. Aanlyn beskikbaar: http:// vonkk.kerkmusiek.co.za.

Zikmund, WG, Babin, BJ, Carr, JC \& Griffin, M. 2013. Business Research Methods, $9^{\text {th }} e d$. Mason, OH: South-Western Cengage Learning. 